\title{
WORK AND RETIREMENT PATTERNS FOR THE G.I. GENERATION, SILENT GENERATION, AND EARLY BOOMERS: THIRTY YEARS OF CHANGE
}

\author{
Richard W. Johnson, Barbara A. Butrica, and Corina Mommaerts
}

CRR WP 2010-8

Date Released: July 2010

Date Submitted: June 2010

\author{
Center for Retirement Research at Boston College \\ Hovey House \\ 140 Commonwealth Avenue \\ Chestnut Hill, MA 02467
}

Tel: 617-552-1762 Fax: 617-552-0191

\begin{abstract}
All of the authors are affiliated with the Urban Institute. Richard W. Johnson is a senior fellow, Barbara A. Butrica is a senior research associate, and Corina Mommaerts is a research assistant. The research reported herein was pursuant to a grant from the U.S. Social Security Administration (SSA) funded as part of the Retirement Research Consortium (RRC). The findings and conclusions expressed are solely those of the author and do not represent the views of SSA, any agency of the Federal Government, the RRC, the Urban Institute, or Boston College.

(C) 2010, by Richard W. Johnson, Barbara A. Butrica, and Corina Mommaerts. All rights reserved. Short sections of text, not to exceed two paragraphs, may be quoted without explicit permission provided that full credit, including (C) notice, is given to the source.
\end{abstract}




\section{About the Center for Retirement Research}

The Center for Retirement Research at Boston College, part of a consortium that includes parallel centers at the University of Michigan and the National Bureau of Economic Research, was established in 1998 through a grant from the Social Security Administration. The Center's mission is to produce first-class research and forge a strong link between the academic community and decision makers in the public and private sectors around an issue of critical importance to the nation's future. To achieve this mission, the Center sponsors a wide variety of research projects, transmits new findings to a broad audience, trains new scholars, and broadens access to valuable data sources.

\section{Center for Retirement Research at Boston College \\ Hovey House \\ 140 Commonwealth Avenue \\ Chestnut Hill, MA 02467 \\ phone: 617-552-1762 fax: 617-552-0191 \\ e-mail: crr@bc.edu \\ crr.bc.edu}

Affiliated Institutions:

The Brookings Institution

Massachusetts Institute of Technology

Syracuse University

Urban Institute 


\begin{abstract}
This study examines how the shifting choices and constraints facing older workers have changed work and retirement patterns over the past 30 years. Health improvements, declines in physical job demands, changes in Social Security rules, and the erosion in traditional defined benefit pension coverage and employer-sponsored retiree health insurance have altered work incentives at older ages. This paper compares labor force exits by older workers born 1913 to 1917 (part of the G.I. Generation), 1933 to 1937 (part of the Silent Generation), and 1943 to 1947 (part of the Baby Boom Generation). The analysis uses 16-year longitudinal panels from the Health and Retirement Study and decades-long administrative earnings records linked to respondents in the Survey of Income and Program Participation.

The results show that early boomers worked longer than members of the Silent Generation, and that the pathways older workers follow out of the labor force have become more complex over time. The median retirement age for men was about one-half year higher in the 1943-47 cohort than in the 1933-37 cohort (62 vs. 61.5), but differences were more pronounced at older ages. By age 65, for example, 40 percent of early boomer men had not yet retired, compared with only 20 percent of Silent Generation men. Both male and female workers in the 1933-37 cohort were much less likely than their counterparts in the 1913-17 cohort to follow the traditional retirement path of exiting the labor force from full-time employment and never returning to work.
\end{abstract}




\section{Policy Abstract}

This study examines how the shifting choices and constraints facing older workers have changed work and retirement patterns over the past 30 years. Health improvements, declines in physical job demands, changes in Social Security rules, and the erosion in traditional defined benefit pension coverage and employer-sponsored retiree health insurance have altered work incentives at older ages. This paper compares labor force exits by older workers born 1913-17 (part of the G.I. Generation), 1933-37 (part of the Silent Generation), and 1943-47 (part of the Baby Boom Generation). The analysis uses 16-year longitudinal panels from the Health and Retirement Study and decades-long administrative earnings records linked to respondents in the Survey of Income and Program Participation.

The results show that early boomers worked longer than members of the Silent Generation, and that the pathways older workers follow out of the labor force have become more complex over time. The median retirement age for men was about one-half year higher in the 1943-47 cohort than in the 1933-37 cohort (62 vs. 61.5), but differences were more pronounced at older ages. By age 65, for example, 40 percent of early boomer men had not yet retired, compared with only 20 percent of Silent Generation men. Both male and female workers in the 1933-37 cohort were much less likely than their counterparts in the 1913-17 cohort to follow the traditional retirement path of exiting the labor force from full-time employment and never returning to work. 


\section{Introduction}

The choices and constraints confronting older workers contemplating retirement have been changing rapidly. Today’s older adults are generally better able to work than previous generations, for example, because health has improved at older ages and jobs have become less physically demanding. Defined contribution (DC) plans have supplanted traditional defined benefit (DB) pensions as the dominant type of employer-sponsored retirement plan. DB plans often penalize participants who work too long, whereas DC plans do not. Employer-sponsored retiree health benefits, which generally provide health insurance to retirees before Medicare begins at age 65, are disappearing, making it more expensive for many workers to retire early. Recent Social Security changes are also increasing work incentives at older ages. The full retirement age (FRA) for Social Security has increased. The retirement earnings test, which reduces payments to employed beneficiaries who earn more than a certain amount, was eliminated in 2000 for those who have reached the FRA. And the delayed retirement credit, which increases Social Security benefits for those who wait until after reaching the FRA to begin collecting, is now eight times as high as it was in the mid-1970s.

These changes are altering retirement behavior. Labor force participation rates among both men and women age 62 and older have soared over the past 15 years as work incentives increased. The traditional retirement pattern, by which older workers leave the labor force directly from full-time employment and never return to work, may be less popular now than it used to be, with more complex patterns becoming the norm. For example, many workers partially retire, moving from full-time to part-time employment, before leaving the labor force completely. And some retirees return to work. As labor supply patterns shift at older ages and traditional retirements become less common, various factors may now influence labor force 
withdrawals in different ways than in the past. For example, the impact of education, pensions, retiree health insurance, and health status on retirement may be changing.

This study examines how retirement behavior changed over a recent 30-year period. It compares labor force exits by older workers in three different five-year cohorts—-those born from 1913 to 1917 (part of the G.I. Generation), 1933 to 1937 (part of the Silent Generation), and 1943 to 1947 (the early years of the Baby Boom Generation). ${ }^{1}$ These cohorts reached age 65 around 1980, 2000, and 2010. Using 16-year longitudinal panels from the Health and Retirement Study and decades-long administrative earnings records linked to respondents in the Survey of Income and Program Participation (SIPP), the analysis shows changes over time in retirement ages, retirement dynamics, and the factors influencing retirement decisions.

The results show that retirement behavior has changed markedly over the past 30 years. The tendency to retire at age 62 remains nearly as strong today as it was in the past, but age 65 is no longer a focal point for retirement. Among men and women who remain at work at age 62, early boomers retired later than those in the Silent Generation born 10 years earlier. Retirement patterns have also become more complex, with more workers partially retiring and returning to work after a retirement spell than in the past.

\section{Background: The Shifting Retirement Environment}

Retirement decisions depend on the costs and benefits of withdrawing from the labor force. The principal cost of retiring is the loss of earnings and fringe benefits (especially health benefits). How much Social Security and pension benefits offset lost earnings, then, influence when older

\footnotetext{
${ }^{1}$ Our generational classifications correspond to those defined by Strauss and Howe (1991). Others use different definitions. The U.S. Census Bureau, for example, defines the Baby Boom Generation as those born 1946-64.
} 
workers retire. The cost of forfeited employer health benefits is often substantial before Medicare becomes available at age 65 , but it is less costly for those whose employers offer retiree health benefits or who may receive benefits through their spouse's health plan. Poor health reduces productivity and makes work less pleasant, especially in jobs that entail physically demanding activities. Consequently, changes over time in Social Security rules, pensions, retiree health plans, health status, and job demands will influence retirement incentives.

\section{Employer-Sponsored Pensions}

The most dramatic change in the retirement environment over the past few decades has probably been the growth in employer-sponsored DC retirement plans and the erosion in traditional DB pension plan coverage. Between 1980 and 2009, the share of private-sector workers participating in DB plans fell from 39 to 20 percent, while the share participating in DC plans but not DB plans increased from 8 to 31 percent (Bureau of Labor Statistics [BLS] 2009; Pension and Welfare Benefits Administration 2001-2002). ${ }^{2}$ Conversions to cash balance plans, which are classified as DB plans for legal and regulatory purposes but which resemble DC plans in many respects, have compounded the decline in traditional DB plans. Cash balance plans, which did not exist before 1985, provided coverage for 23 percent of all private-sector workers in DB plans in 2005 (BLS 2007). Because of these retirement plan shifts, those in our study born between 1913 and 1917 are much more likely to have DB coverage than those born between 1943 and 1947.

\footnotetext{
${ }^{2}$ DB plans continue to dominate in the public sector, however. In 2009, 79 percent of state and local government employers participated in DB pension plans (BLS 2009), and the federal government offers a DB plan to nearly its entire workforce.
} 
The shift away from traditional DB pension plans significantly affects retirement incentives. Once DB plan participants have satisfied the plan's service requirements and reach retirement age, they may leave their employer and begin collecting monthly retirement benefits, which are generally based on earnings and years of service and last until they die. Participants may generally raise their monthly retirement benefits by working beyond the plan's retirement age, as years of service (and sometimes annual earnings) increase. However, the increase in monthly benefits resulting from an additional month of work is usually insufficient to fully offset the loss of a month of benefits. As a result, most traditional DB plans penalize work beyond the plan's retirement age. Numerous studies have found that workers respond to the incentives embedded in DB pension plans by retiring at a relatively young age (e.g., Lumsdaine, Stock, and Wise 1996; Samwick 1998; Stock and Wise 1990).

DC retirement plans, by contrast, do not encourage workers to retire early. Most DC plans function essentially as tax-advantaged savings accounts to which both employers and employees contribute. Workers gain access to their accumulated account balance when they retire. Because the account balance may continue to grow while participants remain in the plan and workers do not forfeit any benefits by remaining with the employer beyond traditional retirement ages, DC plans do not penalize work at older ages. In fact, Friedberg and Webb (2005) found that older workers in DC plans generally retire about two years later than those in DB plans.

Cash balance plans provide incentives similar to those in DC plans (Johnson and Uccello 2004). Employers offering cash balance plans regularly set aside a given percentage of salary for each employee and credit interest on these contributions. Interest credit rates are usually tied to a special benchmark, such as the U.S. Treasury bill rate. As in DC plans, cash balance benefits are 
expressed as an account balance. ${ }^{3}$ As a result, participants do not forfeit benefits by remaining at work beyond the plan's retirement age.

There is some evidence that DB plans better reward work at older ages today than in the past. Our calculations from BLS tabulations show that among private-sector workers in DB plans that specify a retirement age, the share in plans that allow workers to retire at age 62 or younger with full benefits declined from 44 to 30 percent between 1995 and $2005 .{ }^{4}$ Over the same period, the share of DB plan participants who could retire early and receive reduced benefits declined from 96 to 88 percent. It is likely, then, that recent cohorts of older workers with DB plans retire later than their counterparts in earlier cohorts.

\section{Health Benefits}

Six in ten employers offered health insurance benefits to their workers in 2009, with monthly premiums averaging \$402 for single coverage (Kaiser Family Foundation and Health Research and Educational Trust 2009). Premiums are generally shared between employers and employees. Workers with employer health insurance generally forfeit their benefits when they retire, a significant cost when leaving the labor force before age 65. Early retirees not only forego the insurance subsidies that most employers offering coverage provide, they also lose access to the group insurance market. Nongroup health insurance premiums are typically quite expensive for older adults, particularly those with health problems (Pollitz, Sorian, and Thomas 2001). The

\footnotetext{
${ }^{3}$ In cash balance plans, however, these account balances are only bookkeeping devices. Plans pay benefits from commingled funds invested in a pension trust on behalf of all participants.

${ }^{4}$ These estimates are based on data from BLS $(1998,2007)$. The earlier survey is restricted to workers at medium and large private employers (that employ 100 or more employees), whereas the later survey includes all privatesector workers. This discrepancy is unlikely to affect our findings much because most DB plan participants work at medium or large employers. In 2009, only 9 percent of private-sector workers at small employers participated in DB plans, compared with 46 percent of those at firms that employed 500 or more workers (BLS 2009).
} 
cost of losing employer health benefits is lower for workers who wait to retire until age 65, when they can begin Medicare and avoid having to obtain primary coverage in the nongroup market. ${ }^{5}$

Retiree health benefits generally allow workers to continue their employer health insurance coverage after they retire until they qualify for Medicare benefits at age 65. Some retiree health plans also supplement Medicare benefits after age 65. By lowering retirement costs, these benefits reduce work incentives and encourage early labor force withdrawals (Blau and Gilleskie 2001; Johnson, Davidoff, and Perese 2003; Rogowski and Karoly 2000). However, the share of employers offering retiree health benefits has declined dramatically over the past two decades as health care costs have increased. Among large private-sector employers (with 200 or more employers) that provided health benefits, only 29 percent offered retiree health benefits in 2009, down from 66 percent in 1988 (Kaiser Family Foundation and Health Research and Educational Trust 2009). ${ }^{6}$ Additionally, the retiree health benefits that employers provide have generally become less generous over time and now shift more costs to retirees (Johnson 2007; Laschober 2004). This erosion in retiree health benefits is changing work patterns at older ages. $^{7}$

\section{Social Security}

Social Security reforms implemented over the past 30 years, especially the past 10 years, have boosted work incentives. The increase in the FRA raised the penalty for early retirement,

\footnotetext{
${ }^{5}$ Some beneficiaries purchase private supplemental insurance (known as Medigap policies) to help cover Medicare deductibles and copayments and some services excluded from Medicare's benefits package.

${ }^{6}$ Most of this decline occurred in the late 1980s and early 1990s.

${ }^{7}$ The 2010 health reform legislation (the Patient Protection and Affordable Care Act) establishes health insurance exchanges in 2014 that may substantially reduce the cost of nongroup health insurance coverage and thus the importance of retiree health benefits in coming years.
} 
increases in the delayed retirement credit boosted Social Security benefits for those who delay retirement, and the elimination of the retirement earnings test for workers who have reached the FRA removed an apparent tax on work at older ages.

The 1983 amendments to the Social Security Act gradually increased the FRA — the age at which individuals may begin collecting their full retirement benefits—-from 65 to 67 . Beginning with those born in 1938 (who turned 62 in 2000), the FRA increased two months a year until it reached 66 for those born in 1943 (who turned 62 in 2005). The FRA remains at this level for the next several years. It begins increasing two months per year again for those born in 1955 (and turning 62 in 2017), until it reaches 67 for those born in 1960 and later. Retirees may still claim Social Security at age 62, the early entitlement age, but those who face a higher FRA are penalized more. When the FRA is 66, for example, those who begin collecting retirement benefits at age 62 receive only 75 percent of their full benefits, whereas those facing an FRA of 65 receive 80 percent of their full benefits when they begin collecting at 62 .

In addition to penalizing those who retire early, Social Security rewards those who retire later. The delayed retirement credit increases monthly payments for each month that the beneficiary waits beyond the FRA to begin collecting. This credit has increased sharply over time. When first implemented in 1972, it increased benefits by 1 percent for each year that the beneficiary waited beyond the FRA to collect, up to age 72 . The credit increased to 3 percent per year in 1981. The 1983 amendments included additional increases that began with those born in 1925, whose credit was boosted to 3.5 percent per year, but stopped increasing benefits for those who wait beyond age 70 to collect. They further increased the credit by 0.5 percentage points every other year until it reached 8 percent per year for those born in 1943 and later. 
The retirement earnings test reduces Social Security benefits for those who receive benefits while working. The earnings test originally applied to all Social Security beneficiaries, regardless of age. For beneficiaries below the FRA, Social Security withheld $\$ 1$ in benefits for every \$2 of earnings in excess of a specified exempt amount. For beneficiaries at or above the FRA, Social Security withheld \$1 in benefits for every \$3 of earnings in excess of a different higher exempt amount. Beginning in 1981, the earnings test did not apply to working beneficiaries age 70 or older. The benefit reduction while working is partly offset by higher future benefits (although many beneficiaries may not realize that their benefits will increase in later years).

The Senior Citizens’ Freedom to Work Act of 2000 eliminated the retirement earnings test above the FRA. For working beneficiaries below the FRA, the retirement earnings test currently reduces benefits by $\$ 1$ for every $\$ 2$ of earnings in excess of the exempt amount$\$ 14,160$ in 2010 . For working beneficiaries at the FRA, it reduces benefits by $\$ 1$ for every $\$ 3$ of earnings in excess of a higher exempt amount-\$37,680 in 2010. Several studies have found that workers responded to the elimination of the retirement earnings test by working more (Friedberg 2000; Haider and Loughran 2008; Song 2004; Tran 2004) or taking Social Security benefits earlier (Gruber and Orszag 2003; Song and Manchester 2007).

Table 1 shows how Social Security's penalties for taking early benefits and bonuses for delaying retirement differ for the cohorts in our study. The FRA is higher for the 1943-47 birth cohort than earlier cohorts (66 vs. 65), so those in the later cohort who retire at age 62 receive a smaller percentage of their full benefits, especially if they take spousal benefits instead of retired 
worker benefits. ${ }^{8}$ The delayed retirement credit is also higher for later cohorts. As a result, adults born between 1943 and 1947 can increase their monthly Social Security benefits by 144 percent if they wait until age 67 to begin collecting, instead of collecting at age $62 .{ }^{9}$ By contrast, those born between 1913 and 1915 increased their monthly benefits only 127.5 percent by waiting until age 67. The elimination of the retirement earnings test after the FRA creates additional work incentives for those born in later cohorts.

\section{Health Status}

Older Americans are healthier now than they used to be, improving their productivity and ability to work. Figure 1 shows how the percentage of older adults reporting fair or poor health changed between 1983 and 2007. Although this health measure is subjective, survey respondents who report poor health have much higher mortality rates than those who report better health (Dowd and Zajacova 2007; Idler and Benyamini 1997), suggesting that it reflects real health problems. Between 1983 and 2007, the share reporting fair or poor health fell about 7 percentage points at age 55 to 64,10 percentage points at age 65 to 74 , and 7 percentage points at age 75 to 84 . These declines represent substantial relative changes. At age 65 to 74, for example, the share with fair or poor health was nearly one-third lower in 2007 than 1983. Health gains were much more modest at age 45 to 54, however. And at all older ages, health has improved much more slowly (or not at all) since 1998, raising concerns about the health status of future generations of older Americans (Soldo, Mitchell, Tfaily, and McCabe 2007).

\footnotetext{
${ }^{8}$ Instead of receiving Social Security as a retired worker, married (and divorced) beneficiaries may receive payments equal to 50 percent of their spouse's full retirement benefit. Like retired worker benefits, spouse benefits are reduced when they begin before the recipient's FRA, but the reduction factors are larger for spouse benefits.

${ }^{9}$ This calculation assumes that adults who delay claiming stop working at age 62. Some beneficiaries would experience larger increases if they continued to work after age 62.
} 


\section{Job Characteristics}

Between 1971 and 2006 the share of workers in blue-collar occupations fell from 36 to 24 percent, while the share of workers in management, the professions, and services increased from 38 to 51 percent (Johnson, Mermin, and Resseger 2007). As the economy moved away from manufacturing to service and technology-based jobs, fewer Americans engaged in physically demanding work. The share of jobs involving high physical demands (such as strength, bending, or quick reaction time) declined from 8.8 to 7.3 percent between 1971 and 2006, while the share involving moderate or high physical demands (such as standing, walking, or repetitive motion) declined from 56.5 to 46.0 percent (Johnson, Mermin, and Resseger 2007). Between 1992 and 2002, the share of workers age 55 to 60 in jobs that never or almost never involved much physical effort increased by nearly one fifth (Johnson 2004). The decline in physically demanding jobs, combined with improvements in health status, have increased the share of older adults able to work.

\section{Employment Opportunities}

Employment at older ages depends not only on older adults' willingness and ability to work, but also on employers' willingness to hire and retain them. In surveys, employers usually say they value older workers' experience, maturity, and work ethic, but often express concern about their relatively high salaries and benefit costs (Mermin, Johnson, and Toder 2008). One-quarter of employers in a 2006 said they were reluctant to hire older workers (Pitt-Catsouphes et al. 2007). Employers appear to hold less favorable views about older rank-and-file workers than older professionals and managers. In another 2006 survey, for example, 19 percent of employers reported that older rank-and-file workers were less productive than their younger counterparts 
(Munnell, Sass, and Soto 2006). Only 6 percent of employers believed that older professionals and managers were less productive than younger ones.

Some employers appear to discriminate against older workers in hiring decisions. In an experimental study, Lahey (2008) sent resumes to nearly 4,000 firms in the Boston and St. Petersburg, Florida areas. The resumes, which were faxed in pairs in response to employment ads for entry-level jobs, were identical except for the age of the job applicant. Lahey found that resumes from younger women (age 35 or 45 ) generated significantly more positive responses than those from older women (age 50, 55, or 62). These findings are consistent with other evidence of discrimination by employers against older workers (Reynolds, Ridley, and Van Horn 2005; Rosen and Jerdee 1995).

\section{Changing Work and Retirement Patterns}

Perhaps in response to shifts in pension plan design, Social Security rules, retiree health plans, health status, job demands, and employer attitudes, labor force participation rates have changed markedly over the past half century. The share of older men participating in the labor force steadily declined until about 1990, but then began increasing among those age 62 and older (figure 2). Between 1993 and 2009, for example, participation rates increased 20 percent at ages 62 to 64 and 43 percent at ages 65 to 69 . Men born in 1935, then, were less likely to work at ages 62 to 64 than those born in 1915 or those born in 1945. Male participation rates at ages 55 to 61 have not changed much over the past two decades, however. As a result, men born in 1915 were more likely to work at ages 55 to 61 than those born in 1935 or 1945.

Participation rates for older women have fairly steadily increased since the early 1960s, and grew especially rapidly over the past two decades (figure 3). Between 1993 and 2009, female participation rates increased 22 percent at ages 55 to 61, 39 percent at ages 62 to 64 , and 
65 percent at ages 65 to 69 . This growth is partly due to the aging of female cohorts who were always more strongly attached to the labor force than earlier generations.

Although changes in older Americans’ participation rates are well publicized, less is known about other ways in which work is changing at older ages. For example, older adults’ work patterns may be becoming more complex. Many workers now partially retire, moving from full-time to part-time employment before leaving the labor force completely (Cahill, Giandrea, and Quinn 2006). This alternative to the more traditional retirement pattern, in which workers move directly out of the labor force from full-time employment, may be more popular now than in the past. Some evidence, for instance, suggests that older workers became more likely to transition from full-time to part-time employment during the 1970s and 1980s (Peracchi and Welch 1994), although partial retirement certainly existed in the 1980s (Ruhm 1990). Many retirees now return to work after leaving the labor force (Maestas forthcoming), which may also be more common today. Additionally, various factors may now influence labor force withdrawals in different ways than in the past. For example, the impact of education, pensions, retiree health insurance, and health status on retirement may be changing as the retirement landscape shifts.

\section{Data and Methods}

This paper used data from the SIPP and HRS to examine how older adults' work patterns differ in the 1913-17, 1933-37, and 1943-47 birth cohorts. We compared retirement hazard curves and the cumulative probability of remaining in the labor force for each cohort, estimated multivariate hazard models of retirement, and showed how retirement pathways have changed over time. Using two surveys complicated the analysis, but we could not compare retirement behaviors over 
a 30-year span with just one survey. The HRS data provided better measures of retirement and its timing than the SIPP data and included better measures of health, pension coverage, and access to retiree health insurance, but we could observe employment histories near traditional retirement ages for only six years in the 1943-47 HRS cohort.

\section{Survey of Income and Program Participation}

The SIPP consists of a series of panels that follow respondents for about three to four years, collecting data on demographics, employment, earnings, assets, and other characteristics. The first panel began in 1984, and the latest panel began in $2004 .{ }^{10}$ These panels are too short to construct long-term employment histories. However, they have been linked to the Social Security Administration’s Summary Earnings Records (SER) files that extend from 1951 to 2007, allowing us to examine employment patterns for several decades. ${ }^{11}$ Matched earnings records were available for about 95 percent of respondents in the 1984 panel and about 81 percent in the 2004 panel.

Our SIPP samples consisted of adults born between 1913 and 1917 and interviewed in the 1984 panel, when they were age 67 to 71, and those born 20 years later (1933 to 1937) who were interviewed at age 67 to 71 in the 2004 panel. Because health status is correlated with both labor supply and mortality, we must condition both samples on survival to the same relatively narrow age range (67 to 71$)$ to avoid potential biases. To focus on those attached to the labor force at midlife, we also restricted the analysis to respondents with average annual earnings (in 2007

\footnotetext{
10 The 2008 SIPP panel was released while this study was underway, but only the first 12 months of data were available.

${ }^{11}$ Access to the matched SER files is restricted, and researchers must follow strict confidentiality procedures.
} 
wage-adjusted dollars) at age 45 to 49 that exceeded $\$ 6,084$, the amount earned by workers employed half-time at the 2007 federal minimum wage (\$5.85 times 1,040 hours). ${ }^{12}$

The SIPP surveys provided basic demographic information, and the earnings records allowed us to date full and partial retirements that may have occurred outside the survey window. Retirement measures based on earnings data are somewhat problematic, however. The SER indicated annual earnings up to Social Security's taxable maximum for each calendar year. We classified individuals as having fully retired in year $t$ if their earnings in year $t+1$ were zero (and they were not retired in year $t$ ). We computed their age in year $t$ based on the age they reported at the time of the SIPP survey, although these estimated retirement ages may be off by one year depending on what point during the calendar year they actually stopped working. Individuals were classified as partially retired at age $t$ if they had positive earnings that were less than half their average earnings between ages 45 and 49 and if they had positive earnings in year $t+1$. Because some workers with low earnings in year $t$ likely worked full-time part of the year and then fully retired, those with zero earnings in year $t+1$ were classified as having fully retired in year $t$, as noted above. Based on these definitions, our final sample included 1,106 workers from the 1913-17 cohort and 1,883 workers from the 1933-37 cohort who were working and not retired at age 49.

The increase over time in Social Security's taxable maximum introduced another potential source of error into our partial retirement measure. The taxable maximum, at which our earnings records were capped, increased from \$4,200 in 1957 (the year the oldest members of our sample turned 45) to $\$ 32,400$ in 1982 , when the youngest members of our sample turned 45 (SSA 2010). This growth could lead us to understate partial retirement in the earlier cohort, because we may underestimate average earnings at ages 45 to 49 and thus the share of workers

\footnotetext{
${ }^{12}$ Wages were adjusted each year by the change in average economy-wide earnings.
} 
whose later earnings fell substantially below that midlife average. In 1957, annual earnings exceeded the taxable maximum for 30 percent of workers, compared with only 7 percent in 1982 (SSA 2010).

\section{Health and Retirement Study}

Much of our analysis was based on the HRS, a nationally representative longitudinal survey of older Americans that collects detailed information on health status, pensions, wealth, and other factors correlated with employment decisions. Conducted by the University of Michigan with primary funding from the National Institute on Aging, it first interviewed respondents born 1931 to 1941 in 1992, when they were age 51 to 61 . Older cohorts were introduced to the survey in 1993 and 1998, and younger cohorts were introduced in 1998 and 2004. Respondents were resurveyed every other year, and the most recent information when this study was completed was collected in 2008. ${ }^{13}$ We restricted our samples to workers born 1933 to 1937 who were first interviewed in 1992, and those born 1943 to 1947 who were first interviewed in 1998. Both cohorts were age 55 to 59 at the baseline interview.

The detailed employment data collected by the HRS allowed us to construct several different retirement measures. The first measure was based simply on employment; workers were treated as retired when they stopped working or looking for work. The second measure was based on workers' self-identification with retirement. The survey asked respondents whether they considered themselves to be completely retired, partly retired, or not retired at all. We classified those who reported complete or partial retirement as being retired. Our final measure combined the two previous measures, classifying respondents as retired if they were not working and considered themselves to be partially or completely retired. Those who were not working

\footnotetext{
${ }^{13}$ For additional information on the HRS, visit http://hrsonline.isr.umich.edu.
} 
were asked about the month and year when they stopped working, and those who described themselves as retired were asked about the month and year they retired. Combined with survey data on respondents' month and year of birth, this information allowed us to measure retirement ages fairly precisely.

We further restricted the sample to those who did not meet our retirement definition at age 54. Respondents who were not in the labor force at age 54 for reasons other than retirement (such as disability) were also excluded from the sample. When we used the work definition of retirement, our sample included 2,828 respondents from the 1933-37 cohort and 1,505 from the 1943-47 cohort. When we used the self-reported and combined retirement definitions, our sample included 2,596 respondents from the 1933-37 cohort and 1,336 from the 1943-47 cohort.

\section{Analyses}

We began by plotting retirement hazard rates and the cumulative probability of not yet retiring for respondents in our SIPP and HRS samples. We tracked respondents in the SIPP samples for 20 years (from age 50 to 69), and those in the HRS samples for 12 years for the 1933-37 cohort, spanning ages 55-75, and 6 years for the 1943-47 cohort, spanning ages 55 to 65 . The retirement hazard, $\lambda(t)$, is the probability of retiring at age $t$, conditional on not having already retired. The survival function at age $t$, $\mathrm{S}(t)$, was defined as

$$
\mathrm{S}(t)=\mathrm{S}(t-1) *[1-\lambda(t)]
$$

and shows the probability of not yet retiring by age $t$. These curves, then, indicate the likelihood of first retirements. We compared retirement hazards and survival curves for the 1913-17 and 1933-37 cohorts, and for the 1933-37 and 1943-47 cohorts, but we did not compare all three cohorts because retirement definitions and sample selection criteria differed in the SIPP and HRS 
surveys. We estimated rates separately by sex and education, and showed them for each of our retirement definitions.

We then estimated discrete-time hazard models of the log odds of retiring in our HRS samples. The advantage of these models is that they can accommodate time-varying predictors, better enabling us to measure the impact of such factors as age, health, income, and wealth. We estimated hazard models on a sample that included a separate observation for each wave a respondent was not yet retired until they retired, dropped out of the labor force for other reasons, dropped out of the survey, or reached the end of the observation period (1998 for the 1933-37 cohort or 2008 for the 1943-47 cohort). For each interview that respondents remained at risk for retirement (i.e., they were in the labor force but not yet retired), we observed a dichotomous outcome — they retired or they did not. We estimated logit models to regress these outcomes on the predictors, many of which varied over time. Because the data were arranged in person-wave format, the results could be interpreted as discrete-time hazard models (Allison 1984).

Predictors included health, economic, and demographic variables. Health measures consisted of the presence of health problems that limit the type or amount of work and whether the respondent reported fair or poor overall health status (as opposed to excellent, very good, or good). One drawback of the health-related work limitations measure was that in 2004 the HRS stopped asking respondents who reported work limitations in the previous wave whether they continued to have work limitations. We assumed that their health problems continued, even though some people recovered, causing us to overestimate work limitations in 2004, 2006, and 2008.

The economics variables in the model measured the respondent's earnings, household wealth excluding the value of housing, and employee benefits. Earnings and wealth were 
measured as natural logs to account for skewness in their distributions, and expressed in constant 2008 dollars (as adjusted by the change in the consumer price index). The model included indicators of any DB pension plan coverage and DC retirement plan coverage but no DB plan coverage. It also included an indicator of whether the respondent's employer offered retiree health insurance. Additionally, we controlled for age, education, race and ethnicity, and marital status. Each of the predictors were lagged one wave, so the model indicated the impact of healthrelated work limitations in 2004, say, on the likelihood of retiring between 2004 and 2006 (and reporting being retired in 2006). The models were estimated for each of the three retirement measures, separately for men and women in each cohort.

A final set of tabulations computed the likelihood of alternative pathways into retirement for the two SIPP cohorts. For men and women not retired at age 50, we computed the share who moved between work, partial retirement, and full retirement by age 69, as well as the share who returned to work after retiring. We compared outcomes for the 1913-17 and 1933-37 cohorts.

\section{Results}

We first compare retirement rates for men and women in the G.I. Generation and Silent Generation, and then for men and women in the Silent Generation and Boomer Generation. We next show the results of our retirement models for the Silent Generation and Boomer Generation. The final section compares work transitions between age 50 and 69 for men and women in the G.I. Generation and the Silent Generation. 


\section{Retirement Rates in the G.I. and Silent Generations}

Before comparing retirement rates for men and women in the 1913-17 and 1933-37 cohorts, we show how other characteristics of the two cohorts differ (table 2). Men and women in the Silent Generation were much better educated than those in the earlier G.I. Generation. For example, only 12.9 percent of men born 1933 to 1937 who were working and not retired at age 49 failed to complete high school, compared with 47.1 percent of their counterparts born 1913 to 1917. About half of women born 1933 to 1937 who were working and not retired at age 49 had attended college, up from about a quarter of those born 20 years earlier. Additionally, nonHispanic whites made up a smaller share of the later generation of workers than the earlier generation, and the later generation were much less likely to report health-related work limitations at age 67 to 71 .

Figure 4 shows retirement hazard rates for men in the 1913-17 and 1933-37 cohorts, where retirement is defined as moving from full-time (or nearly full-time) employment to full or partial retirement. The risk of retiring was low for both cohorts up to age 60. Hazards for the Silent Generation men increased sharply at age 61, spiked at age 62 (at 31 percent) when early Social Security retirement benefits became available, and spiked again at age 65 when full retirement benefits and Medicare became available. For men born 20 years earlier, retirement hazards rate remained low at age 61 and spiked at age 62, rising 14 percentage points to 23 percent. They rose substantially at ages 64 and especially 65, when the retirement hazard reached 52 percent, before dropping to 24 percent at age 66 .

As suggested by the hazard rates, men in the Silent Generation generally retired earlier than those in the G.I. Generation. The median retirement age (when half of men working at age 49 had fully or partially retired) fell from 61.6 for those born 1913 to 1917 to 59.3 for those born 
1933 to 1937 (figure 5). The younger generation was also more likely to retire at much earlier ages. About 36 percent of men born 1933 to 1937 retired by age 56, compared with only 18 percent of men born 1913 to 1917 . However, men in the later generation were as likely as those in the earlier generation to work at much older ages, because so many men in the earlier generation retired at age 65 . About 12 percent of men in both cohorts waited until after age 65 to retire.

Unlike men, women in the Silent Generation employed at age 49 did not retire later than those in the earlier G.I. Generation. Retirement hazards were similar for women in both cohorts, spiking at age 62 and especially at age 65 (figure 6). Women in the younger cohort were less likely to retire at age 64 and later. The retirement hazard for women born 1933 to 1937, for example, peaked at 36 percent at age 65 and then fell to 12 percent at age 66 . The age-65 peak was higher (46 percent) for women born 20 years earlier, and fell less sharply (to 32 percent) at age 66. The median retirement was 59 for women in both cohorts, although those in the later cohort were somewhat more likely to remain at work and not yet retired by age 65 than those born in the earlier cohort (figure 7).

Figures 8 and 9 compare the cumulative probability of remaining employed and not retiring by educational attainment for men and women. Comparing men born 1913 to 1917 and those born 1933 to 1937, we see that median retirement ages fell over the 20-year period for both men who did not complete high school and for those with at least some college education. Among men in the earlier cohort still working at age 60, those who attended college tended to retire later than those who did not complete high school. These educational differences were somewhat smaller among men born 1933 to 1937 . For women, retirement trends vary with education. Women's median retirement age was lower in the 1933-37 cohort than the 1913-17 
cohort among those who attended college, but higher among those who did not complete high school. Whereas women with at least some college education in the 1913-17 cohort tended to retire later than their counterparts who did not complete high school, college-educated women in the 1933-37 cohort tended to retire earlier than their less-educated counterparts.

\section{Retirement Rates in the Silent and Boomer Generations}

Several factors that tend to influence retirement rates changed significantly for men and women employed at age 54 between the 1933-37 and 1943-47 birth cohorts, as reported in table 3. Both men and women in the later cohort were much better educated than those in the earlier cohort. For example, more than one-third of Boomer men completed college, compared with less than one-fourth of men in the Silent Generation. Boomer men (but not women) reported better health than their counterparts in the Silent Generation, and Boomer women (but not men) earned significantly more than their counterparts in the earlier generation. Both men and women born 1943-47 were less likely than those born 10 years earlier to work for employers offering retiree health insurance. Employed boomer women were also less likely to have DB pension coverage and more likely to have DC plan coverage than those born 10 years earlier. Surprisingly, however, the share of men with any DB coverage or with DC coverage only did not differ significantly for the two cohorts.

Under each of our three retirement measures, retirement hazard rates were quite similar for men in the two cohorts up to age 62, but later-cohort men were much less likely to retire after age 62 than those born 10 years earlier. Consider men's hazard rates when retirement was defined as stopping paid work and describing oneself as retired. For both cohorts, the retirement hazard began slowly increasing at age 59, spiked sharply at age 62, fell back, and then spiked again at age 65 (figure 10). The hazard for Silent Generation men, for example, increased from 9 
percent at age 61 to 27 percent at age 62, and then fell to 15 percent at age 63. Up to age 62, hazards for Baby Boomer Generation men were only a few percentage points smaller than for the Silent Generation men, spiking to 22 percent at age 62. Baby Boomer men who had not retired by age 62, however, exhibited much lower retirement rates than those born 10 years earlier. For example, the retirement hazard spiked to 26 percent at age 65 for men born 1933 to 1937, but increased only modestly, to 7 percent, for men born 1943 to 1947 . Patterns were similar when we defined retirement based on employment status alone (regardless of self-described retirement status) (figure 11) or on self-described retirement status alone (regardless of employment) (figure 12).

Because retirement hazards before age 62 were similar for the Silent Generation and Baby Boomer Generation men, the share retired by 62 did not differ much between the cohorts. Using the retirement definition that combined employment status and self-reported retirement status, we found that only 53 percent of Silent Generation men and 47 percent of Boomer men had retired by age 62 (figure 13). At later ages, however, the share retired was much lower for the Boomer men than the Silent Generation men. By age 65, for example, 75 percent of Silent Generation men had retired, compared with only 57 percent of Boomer men. Over the 10-year period, the median retirement age fell from 61.8 for the Silent Generation men to 62.7 percent for the Boomer men. Again, patterns were similar under alternative retirement definitions (figures 14 and 15).

As we observed for men, retirement hazard patterns were similar for women born between 1933 and 1937 and those born 10 years later. The discussion focuses on the retirement definition that combined employment status and self-reported retirement status (figure 16). The results were similar for the other two definitions (figures 17 and 18). Retirement rates were 
somewhat lower at most ages for the more recent Baby Boomer cohort, and cohort differences for women (unlike those for men) became apparent before age 62. For working women in both cohorts, retirement hazards spiked at age 62, but the spike was much lower for the Boomer women than the Silent Generation women (17 vs. 26 percent). Retirement hazards spiked again at age 65 for the Silent Generation women (at 29 percent), but not for the Boomer women. The median retirement was 62.6 years for the 1943-47 birth cohort of women, compared with 61.5 years for women born 10 years earlier (figure 19). Cohort differences in the cumulative probability of retiring were similar under the other retirement definitions (figures 20 and 21). Retirement trends varied by education, but most differences did not become apparent until age 62. The comparisons defined retirement as ending paid employment and describing oneself as fully or partially retired. For men working at age 54, retirement rates were similar through age 61 for those who did not complete high school and those with at least some college education in both the Silent Generation and Boomer cohorts (figure 22). Beginning at age 62, retirement rates were lower in both cohorts for men with more education. Additionally, retirement rates were lower among Boomer men than Silent Generation men for those who did not complete high school and for those who attended college. The delay in retirement at older ages was not restricted only to well-educated men. For women, Boomers who attended college delayed retirement longer than their Silent generation counterparts, especially at 62 and older ages (figure 23). However, Boomer women who did not complete high school were more likely to retire before age 62 than those born 10 years earlier. Meaningful educational differences in retirement patterns were not apparent among Silent Generation women. 


\section{Retirement Model Estimates for the Silent and Boomer Generations}

Table 4 reports results from the retirement hazard models estimated on a sample of male HRS respondents born between 1933 and 1937 and another sample of men in the HRS born between 1943 and 1947. The table shows estimated marginal effects of various worker characteristics on the likelihood of retirement, under our three alternative retirement definitions.

Health problems and DB pension coverage substantially increased retirement probabilities for men in both generations. Boomer men born 1943 to 1947 in fair or poor health were 11.6 percentage points more likely to retire than their counterparts in better health, under the retirement definition that combined employment status with self-reported retirement status. In relative terms, they were 77 percent more likely to retire than those in better health. Silent Generation men born 1933 to 1937 in fair or poor health were 5.2 percentage points, or 31 percent, more likely to retire than their healthier counterparts. The presence of a health-related work limitation also increased retirement probabilities, but the effects were not significant in the later cohort, perhaps because (as noted earlier) we were unable to measure work limitations precisely in 2004, 2006, and 2008. Relative to working men who did not participate in any retirement plan on the current job, those with DB pension coverage were 7.9 percentage points (or 52 percent) more likely to retire in the 1943-47 cohort, and 8.5 percentage points (or 51 percent) more likely to retire in the 1933-37 cohort.

Retirement probabilities also increased with age for men in both cohorts, but the effects were generally larger for men in the earlier cohort. Men age 60 were substantially more likely to retire by the next survey wave (when they would have reached age 62) than younger men. For men in the Silent Generation, retirement rates were 24.7 percentage points (or 149 percent) higher at age 60 than age 55 under the retirement definition that combined employment status 
and self-reported retirement status. For men in the Boomer Generation, retirement rates were only 16.3 percentage points (or 108 percent) higher at age 60. Generational differences were similar at older ages.

Hispanic men were less likely to retire than non-Hispanic white men in both generations, but the effects were larger in the Boomer Generation. There were no significant differences in retirement rates (when we controlled for other factors) between African American and nonHispanic white men. When we defined retirement solely by employment status, we found that married men were significantly less likely to retire than single men among those born 1933 to 1937, but not among those born 10 years later. Marital status did not significantly affect men’s retirement decisions in either generation under our other two definitions.

For men born 1933 to 1937, household wealth and access to retiree health insurance significantly increased retirement probabilities, whereas a bachelor’s degree significantly reduced retirement probabilities. ${ }^{14}$ When we defined retirement as having stopped work and classifying oneself as retired, for example, men in the Silent Generation with a bachelor's degree were 5.8 percentage points (or 35 percent) less likely to retire than their counterparts with only a high school diploma. None of these factors, however, significantly affected retirement decisions for men born 1943 to 1947.

Table 5 shows retirement model results for women in the Silent Generation and Boomer Generation. As we saw with men, the effect of age on the likelihood of retiring by the next survey wave increased substantially at age 60. Again, though, age had a larger effect among those born between 1933 and 1937 than those born 10 years later. Health problems also substantially increased women's retirement probabilities. When retirement was defined as no longer working and describing oneself as retired, Boomer women who reported health problems

\footnotetext{
${ }^{14}$ However, men in households with no wealth (or negative wealth) retired earlier than other men, all else equal.
} 
that limited the type or amount of work they could perform were 14.5 percentage points (or 87 percent) more likely to retire than those who did not report health problems. The effects were smaller for women in the Silent Generation.

Employee benefits appear to have stronger effects on women's retirement rates now than in the recent past. Under two of our retirement definitions, access to retiree health insurance significantly increased retirement rates for Boomer women but not for Silent Generation women. Participation in DC retirement plans significantly reduced retirement rates for Boomer women under all three of our retirement definitions, but did not have a significant impact for the earlier Silent Generation women under two of our definitions. Household wealth generally increased retirement rates for women in both generations (except that Silent Generation women in households with no wealth or negative wealth also tended to retire early).

The impact of demographic characteristics on women’s retirement decisions also appears to be changing. African American and Hispanic working women born 1943 to 1947 were significantly more likely to retire than their non-Hispanic white counterparts, but racial and ethnic differences were generally insignificant among women born 10 years earlier. Married working women were significantly more likely to retire than their unmarried counterparts among those born 1933 to 1937, but not among those born 1943 to 1947. Educational differences were insignificant in both cohorts.

\section{Retirement Transitions}

Table 6 shows work transitions between age 50 and 69 for men and women in the SIPP, comparing patterns for the G.I. Generation and the Silent Generation. The so-called traditional retirement pattern, in which workers transition from full-time or nearly full-time work directly to 
complete retirement and never return to work, has become much less common over time. Among those born 1913 to 1917 and not yet retired (fully or partially) at age 49, about one-half of men (51.1 percent) and two-fifths of women (60.1 percent) followed this traditional route into retirement. This share fell to about one-third (34.3 percent of men and 37.4 percent of women) among their counterparts born 20 years later. At the same time, workers have become much more likely to partially retire before retiring completely. For example, 45.4 percent of working men and 41.3 percent of working women born between 1933 and 1937 partially retired after age 50, compared with only 32.8 percent of men and 25.3 percent of women born 20 years earlier. The later cohort was also much more likely to have "unretired" than the earlier cohort. About 26 percent of men and 29 percent of women born 1933 to 1937 returned to full-time or nearly fulltime employment after fully or partially retiring.

Complex pathways to retirement remain much less common among workers with limited education than among those who completed high school or attended college. Among workers born 1933 to 1937, 44.8 percent of men (table 7) and 42.6 percent of women (table 8) who did not complete high school followed the traditional retirement path, moving directly out of the labor force from full-time employment and never returning to work before age 70. By contrast, only 32.0 percent of their male counterparts and 34.4 percent of their female counterparts who attended college followed this traditional path. The share of college-educated female workers who followed the traditional retirement pathway was nearly twice as high in the G.I. Generation as in the Silent Generation. 


\section{Conclusions}

Retirement patterns have changed sharply over the past 30 years. Men born 1933 to 1937 retired much earlier, on average, than those born 20 years earlier. The trend reversed 10 years later. Early Boomer men born 1943 to 1947 generally retired later than those born 1933 to 1937. Women born 1933 to 1937 were much more likely to participate in the labor force than those born 1913 to 1917. Among women working at age 49, however, retirement rates were quite similar in the two cohorts. Like men, early Boomer women born 1943 to 1947 generally retired later than women in the Silent Generation born 10 years earlier.

Retirement patterns are also becoming more complex, especially among well-educated workers. The traditional retirement pattern, in which workers transition from full-time or nearly full-time work directly to complete retirement and never return to work, was the norm among workers in the G.I. Generation born 1913 to 1917 . Only about one-third of workers born 20 years later followed this traditional pattern. Instead, more than two-fifths partially retired, moving to part-time work before leaving the labor force completely, and more than one-quarter unretired, returning to work after a retirement spell. These trends will likely continue or even intensify once members of the Boomer Generation move into their mid to late sixties.

The rapid growth in married women's labor force participation over the past 40 years is now transforming retirement decisions. Among Silent Generation workers born 1933 to 1937, married women retired earlier than unmarried women, perhaps because many followed their older husbands out of the labor force. By the time Boomer Generation workers born 1943 to 1947 began exiting the labor force, the retirement gap between married and unmarried women had disappeared, perhaps because women are now more likely than in the past to make retirement decisions appropriate to their own careers and financial security. For example, 
Boomer women generally responded more to retiree health insurance availability and DC retirement plan participation than earlier generations. And health-related work limitations had larger effects on retirement decisions for Boomer women, who are now more likely than past generations to remain at work unless they develop health problems.

The mechanisms that have traditionally regulated retirement behavior are changing or fading away. Social Security's FRA is now 65 instead of 66, the retirement earnings test was eliminated beyond the FRA, and the delayed retirement credit has increased sharply. Employers are now less likely to offer retiree health insurance. Private-sector workers are much less likely to be covered by traditional DB pension plans today than 30 years ago. These pensions create strong incentives for workers to leave at the plan's retirement age, when benefits become available, and the security of guaranteed monthly benefits allowed pensioners to remain outside the labor force once they retired. In light of these changes, then, it is perhaps not surprising that retirement patterns are now more complex and varied than in the past. Age 65, for example, is no longer a focal point for retirements. Among G.I. Generation men born 1913 to 1917 who were still working at age 64 , slightly more than half retired at age 65 . That figure fell to about 26 percent for their counterparts in the Silent Generation born 1933 to 1937, and to 7 percent for Boomer Generation men born 1943 to 1947. We need more research to understand better what is driving these changes.

Sixty-two is now the most common retirement age by far. More than one-fifth of men born 1943 to 47 working at age 61 retired at age 62 . While average retirement ages have been creeping up recently and labor force participation rates have surged after age 62, the share of adults retired by age 62 had not fallen much, especially among men. In light of the financial benefits of working longer and overall improvements in employment prospects at older ages, it is 
surprising that participation rates have not increased more among men in their late fifties and early sixties. As policymakers debate the wisdom of increasing Social Security’s early entitlement age, understanding why so many worker continue to retire by age 62 is a crucial research challenge.

\section{References}

Allison, Paul D. 1984. Event History Analysis. Beverly Hills, CA: Sage.

Blau, David M., and Donna B. Gilleskie. 2001. "Retiree Health Insurance and the Labor Force Behavior of Older Men in the 1990s.” Review of Economics and Statistics 83(1): 64-80.

BLS. See Bureau of Labor Statistics.

Bureau of Labor Statistics. 1998. "Employee Benefits in Medium and Large Private Establishments, 1995.” Bulletin 2496. Washington, DC: U.S. Department of Labor. http://www.bls.gov/ncs/ebs/sp/ebbl0015.pdf.

—. 2007. "National Compensation Survey: Employee Benefits in Private Industry in the United States, 2005.” Washington, DC: U.S. Department of Labor. http://www.bls.gov/ncs/ebs/sp/ebbl0022.pdf.

- 2009. "National Compensation Survey: Employee Benefits in the United States, March 2009.” Bulletin 2731. Washington, DC: U.S. Department of Labor. http://www.bls.gov/ncs/ebs/benefits/2009/ebbl0044.pdf.

- 2010. "Labor Force Statistics from the Current Population Survey.” Washington, DC: U.S. Department of Labor. http://data.bls.gov:8080/PDQ/outside.jsp?survey=ln.

Cahill, Kevin E., Michael D. Giandrea, and Joseph F. Quinn. 2006. "Retirement Patterns from Career Employment.” The Gerontologist 46(4): 514-23.

Federal Interagency Forum on Aging-Related Statistics. 2008. Older Americans 2008: Key Indicators of Well-Being. Washington, DC: U.S. Government Printing Office. 
Friedberg, Leora. 2000. “The Labor Supply Effects of the Social Security Earnings Test.” The Review of Economics and Statistics 82(1): 48-63.

Friedberg, Leora, and Anthony Webb. 2005. "Retirement and the Evolution of Pension Structure.” Journal of Human Resources 40(2): 281-308.

Gruber, Jonathan, and Peter Orszag. 2003. "Does the Social Security Earnings Test Affect Labor Supply and Benefits Receipt?” National Tax Journal 56(4): 755-73.

Haider, Steven J., and David S. Loughran. 2008. "The Effect of the Social Security Earnings Test on Male Labor Supply: New Evidence from Survey and Administrative Data.” Journal of Human Resources 43(1): 57-87.

Idler, Ellen L., and Yael Benyamini. 1997. "Self-Rated Health and Mortality: A Review of Twenty-Seven Community Studies.” Journal of Health and Social Behavior 38(1): 2137.

Johnson, Richard W. 2004. “Trends in Job Demands among Older Workers, 1992-2002.” Monthly Labor Review 127(7): 48-56.

— 2007. "What Happens to Health Benefits after Retirement?” Chestnut Hill, MA: Center for Retirement Research at Boston College.

Johnson, Richard W., and Cori E. Uccello. 2004. "Cash Balance Plans: What Do They Mean for Retirement Security?” National Tax Journal 57(2, Part 1): 315-28.

Johnson, Richard W., Amy J. Davidoff, and Kevin Perese. 2003. "Health Insurance Costs and Early Retirement Decisions.” Industrial and Labor Relations Review 56(4): 716-29.

Johnson, Richard W., Gordon B. T. Mermin, and Matthew Resseger. 2007. "Employment at Older Ages and the Changing Nature of Work.” AARP Public Policy Institute Report 2007-20. Washington, DC: AARP.

Kaiser Family Foundation and Health Research and Educational Trust. 2009. Employer Health Benefits 2009 Annual Survey. Washington, DC: Kaiser Family Foundation and Health Research and Educational Trust.

Lahey, Joanna N. 2008. “Age, Women, and Hiring: An Experimental Study.” Journal of Human Resources 43(1): 30-56.

Laschober, Mary. 2004. "Trends in Medicare Supplemental Insurance and Prescription Drug Benefits, 1996-2001.” Menlo Park, CA: Henry J. Kaiser Family Foundation.

Lumsdaine, Robin L., James H. Stock, and David A. Wise. 1996. "Retirement Incentives: The Interaction between Employer-Provided Pensions, Social Security, and Retiree Health 
Benefits.” In The Economic Effects of Aging in the United States and Japan, edited by Michael D. Hurd and Naohiro Yashiro (261-93). Chicago: University of Chicago Press.

Maestas, Nicole. Forthcoming. "Back to Work: Expectations and Realizations of Work after Retirement.” Journal of Human Resources.

Mermin, Gordon B. T., Richard W. Johnson, and Eric J. Toder. 2008. "Will Employers Want Aging Boomers?” The Retirement Policy Program Discussion Paper No. 08-04. Washington, DC: The Urban Institute.

Munnell, Alicia H., Steven A. Sass, and Mauricio Soto. 2006. "Employer Attitudes Towards Older Workers: Survey Results.” Work Opportunities for Older Americans Series 3. Chestnut Hill, MA: Center for Retirement Research at Boston College.

National Center for Health Statistics. 2010. "Health Data Interactive.” http://www.cdc.gov/nchs/hdi.htm.

Pension and Welfare Benefits Administration. 2001-2002. "Private Pension Plan Bulletin: Abstract of 1998 Form 5500 Annual Reports." http://www.dol.gov/ebsa/PDF/1998pensionplanbulletin.pdf.

Peracchi, Franco, and Finis Welch. 1994. "Trends in Labor Force Transitions of Older Men and Women.” Journal of Labor Economics 12(12): 210-42.

Pitt-Catsouphes, Marcie, Michael A. Smyer, Christina Matz-Costa, and Katherine Kane. 2007. "The National Study Report: Phase II of the National Study of Business Strategy and Workforce Development.” Chestnut Hill, MA: Center on Aging and Work at Boston College.

Pollitz, Karen, Richard Sorian, and Kathy Thomas. 2001. "How Accessible Is Individual Health Insurance for Consumers in Less-than-Perfect Health?” Washington, DC: Kaiser Family Foundation.

Reynolds, Scott, Neil Ridley, and Carl E. Van Horn. 2005. “A Work-Filled Retirement: Workers’ Changing Views on Employment and Leisure.” Worktrends 8.1. http://www.heldrich.rutgers.edu/Resources/Publication/191/WT16.pdf.

Rogowski, Jeannette, and Lynn Karoly. 2000. "Health Insurance and retirement Behavior: Evidence from the Health and Retirement Survey.” Journal of Health Economics 19(4): 529-39.

Rosen, Benson, and Thomas H. Jerdee. 1995. "The Persistence of Age and Sex Stereotypes in the 1990s: The Influence of Age and Gender in Management Decisionmaking.” Public Policy Institute Issue Brief No. 22. Washington, DC: AARP. 
Ruhm, Christopher J. 1990. “Bridge Jobs and Partial Retirement” Journal of Labor Economics 8(4): 482-501.

Samwick, Andrew A. 1998. "New Evidence on Pensions, Social Security, and the Timing of Retirement.” Journal of Public Economics 70(2): 207-36.

Social Security Administration. 2010. Annual Statistical Supplement to the Social Security Bulletin, 2009. Washington, DC.

Soldo, Beth J., Olivia S. Mitchell, Rania Tfaily, and John F. McCabe. 2007. “Cross-cohort Differences in Health: A Multi-Level Analysis of Aggregate and Individual Influences." In Redefining Retirement, edited by Brigitte Madrian, Olivia S. Mitchell, and Beth Soldo (138-58). New York: Oxford University Press.

Song, Jae G. 2004. "Evaluating the Initial Impact of Eliminating the Retirement Earnings Test." Social Security Bulletin 65(1): 1-15.

Song, Jae G., and Joyce Manchester. 2007. "New Evidence on Earnings and Benefit Claims Following Changes in the Retirement Earnings Test in 2000.” Journal of Public Economics 91(3-4): 669-700.

SSA. See Social Security Administration.

Stock, James H., and David A. Wise. 1990. "Pensions, the Option Value of Work, and Retirement.” Econometrica 58(5): 1151-80.

Strauss, William, and Neil Howe. 1991. Generations: The History of America's Future, 1584 to 2069. New York: William Morrow \& Company.

Tran, Bac V. 2004. "The Impact of the Repeal of the Retirement Earnings Test on the Labor Supply of Older Workers.” College Park, MD: University of Maryland. 
Figure 1. Percentage of Older Americans Reporting Fair or Poor Health, by Age, 1983-2007

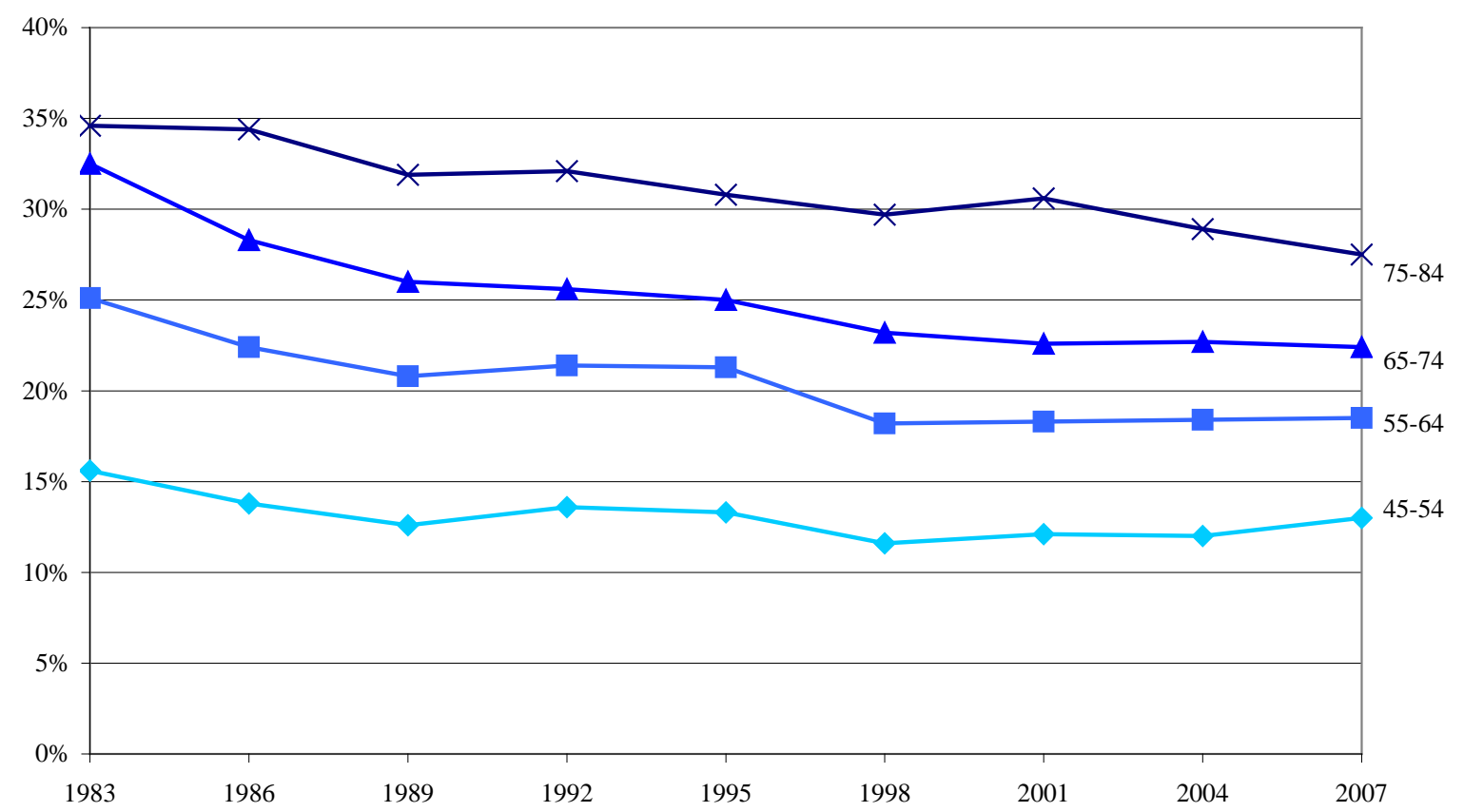

Source: Authors' calculations from the National Center for Health Statistics (2010).

Figure 2. Older Men's Labor Force Participation Rates, by Age, 1963-2009 (\%)

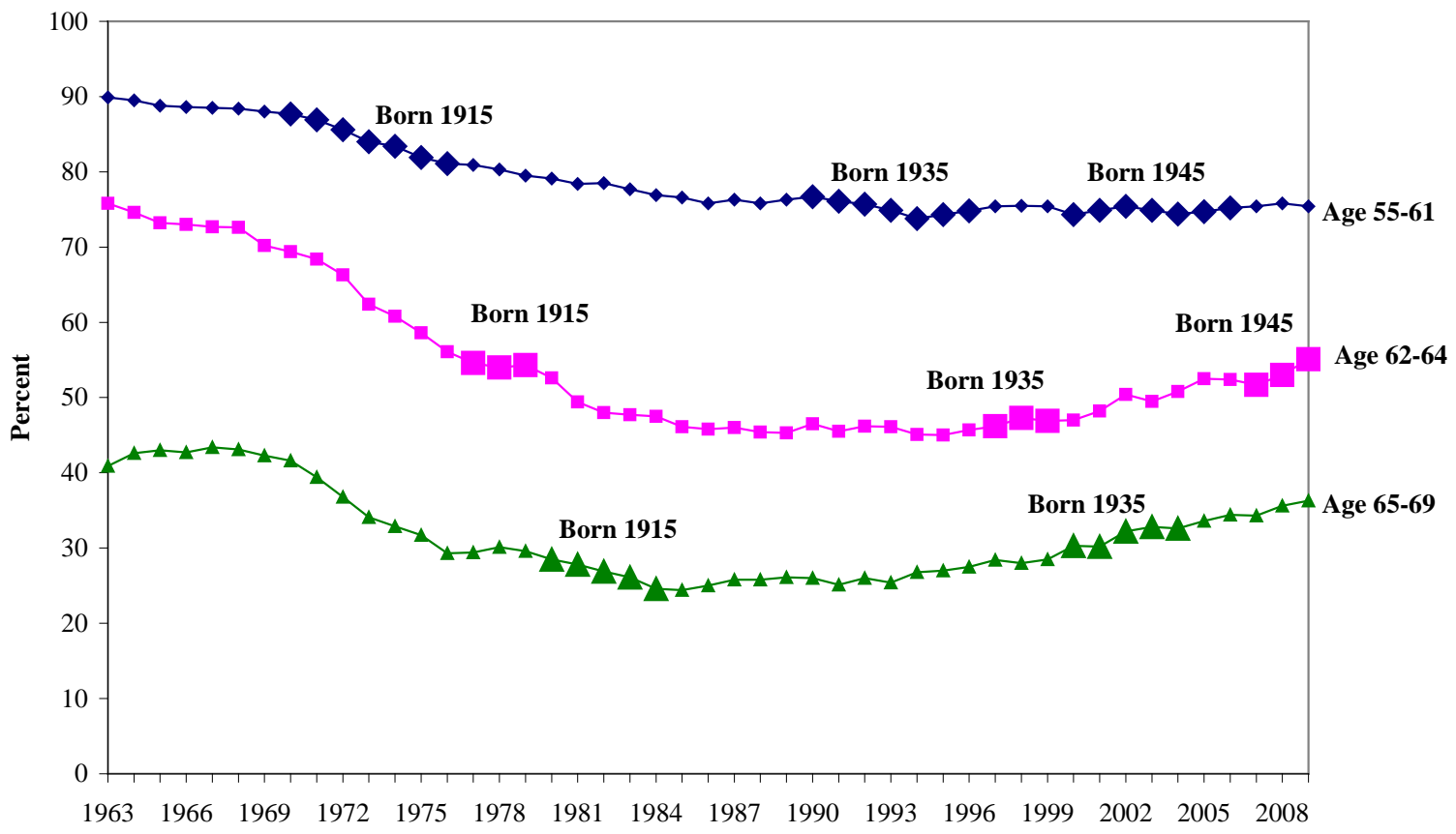

Source: Federal Interagency Forum on Aging-Related Statistics (2008) and authors' calculations from BLS (2010). 
Figure 3. Older Women's Labor Force Participation Rates, by Age, 1963-2007 (\%)

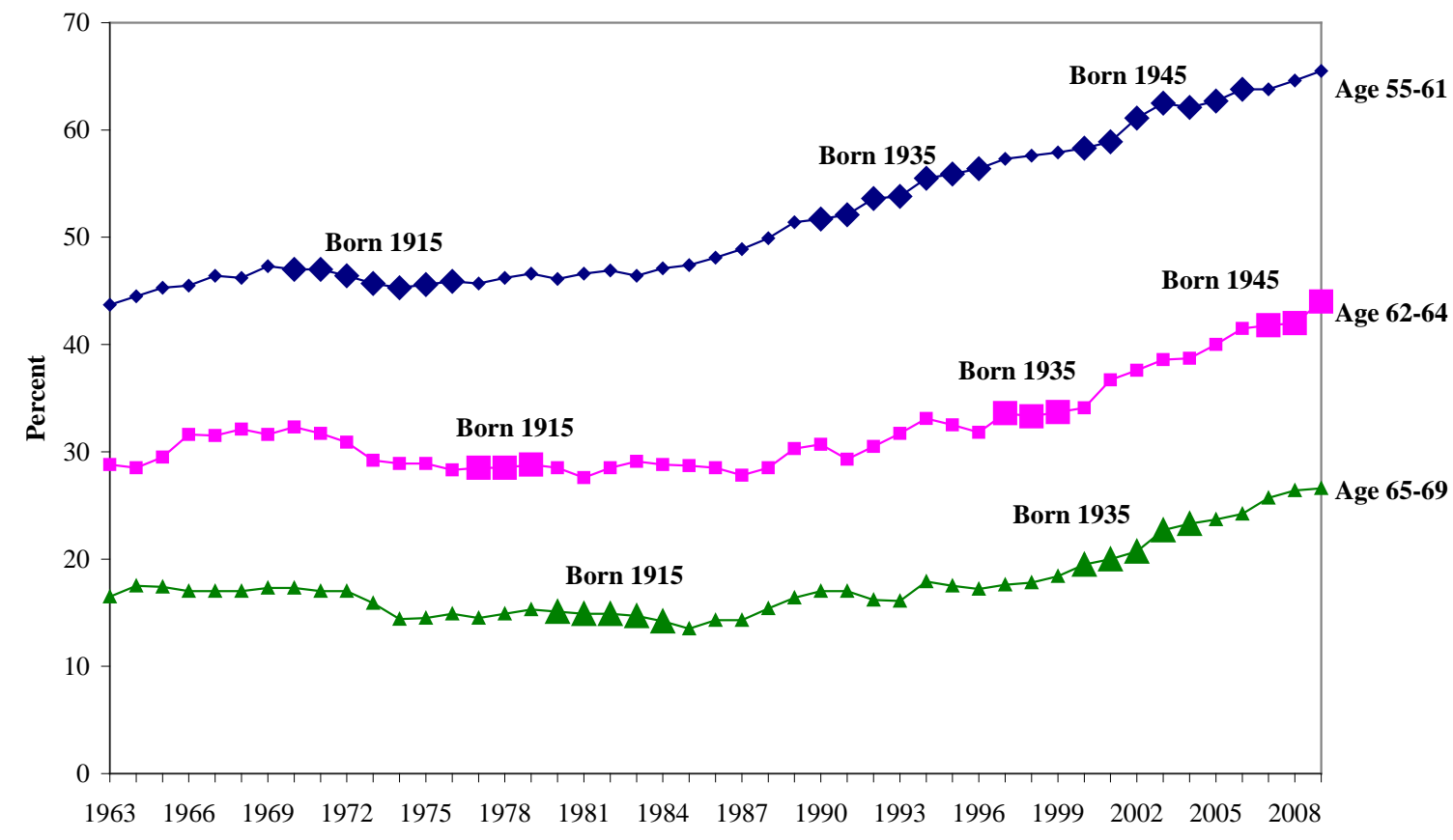

Source: Federal Interagency Forum on Aging-Related Statistics (2008) and authors' calculations from BLS (2010).

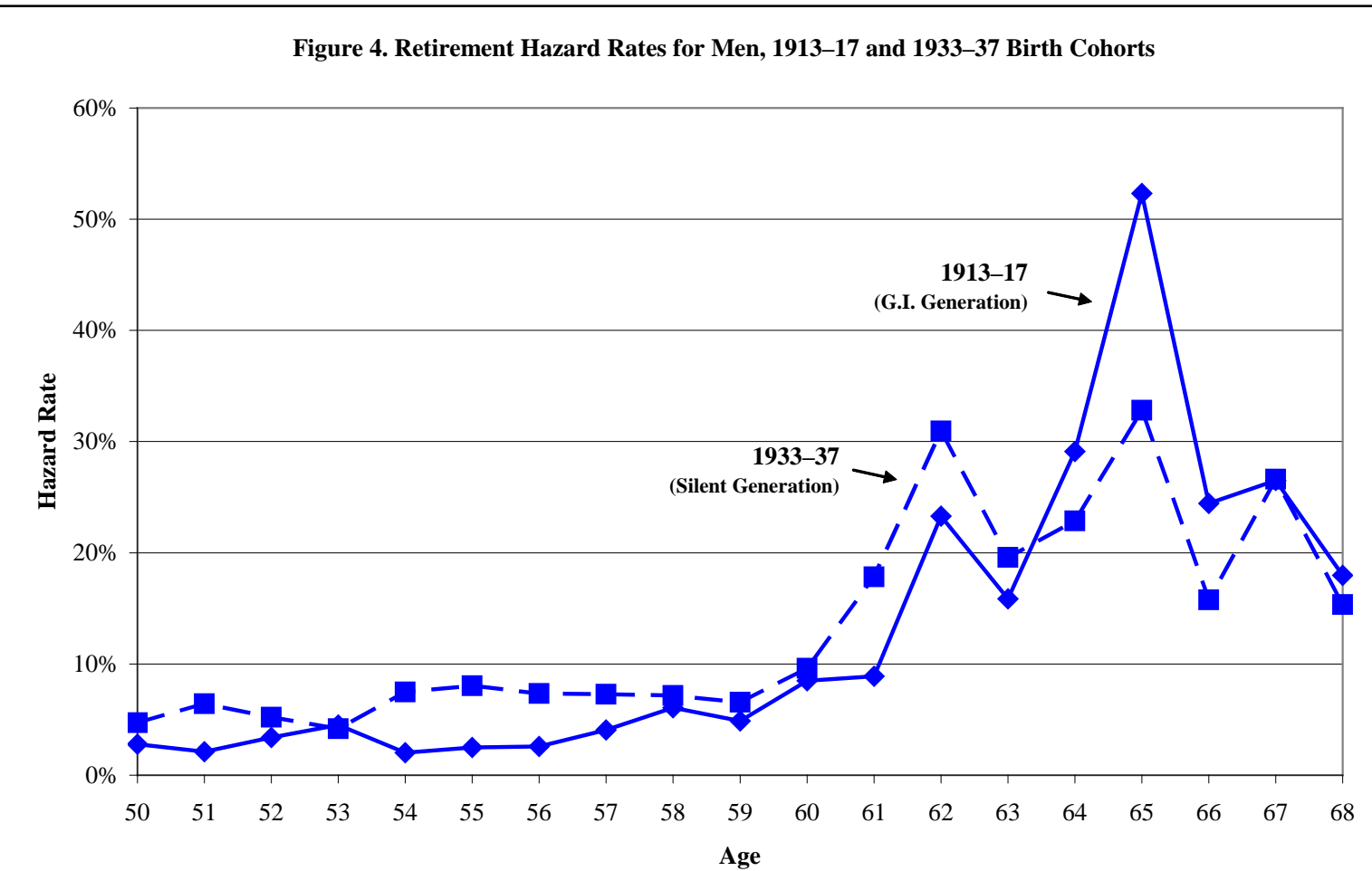

Source: Authors' computations from the SIPP, matched to administrative earnings records.

Note: Sample is restricted to men who were working full-time at age 49 (as defined in the text). Workers are classified as having retired when they experience a significant drop in their earnings (partially retired) or first receive zero earnings in a calendar year (fully retired). 


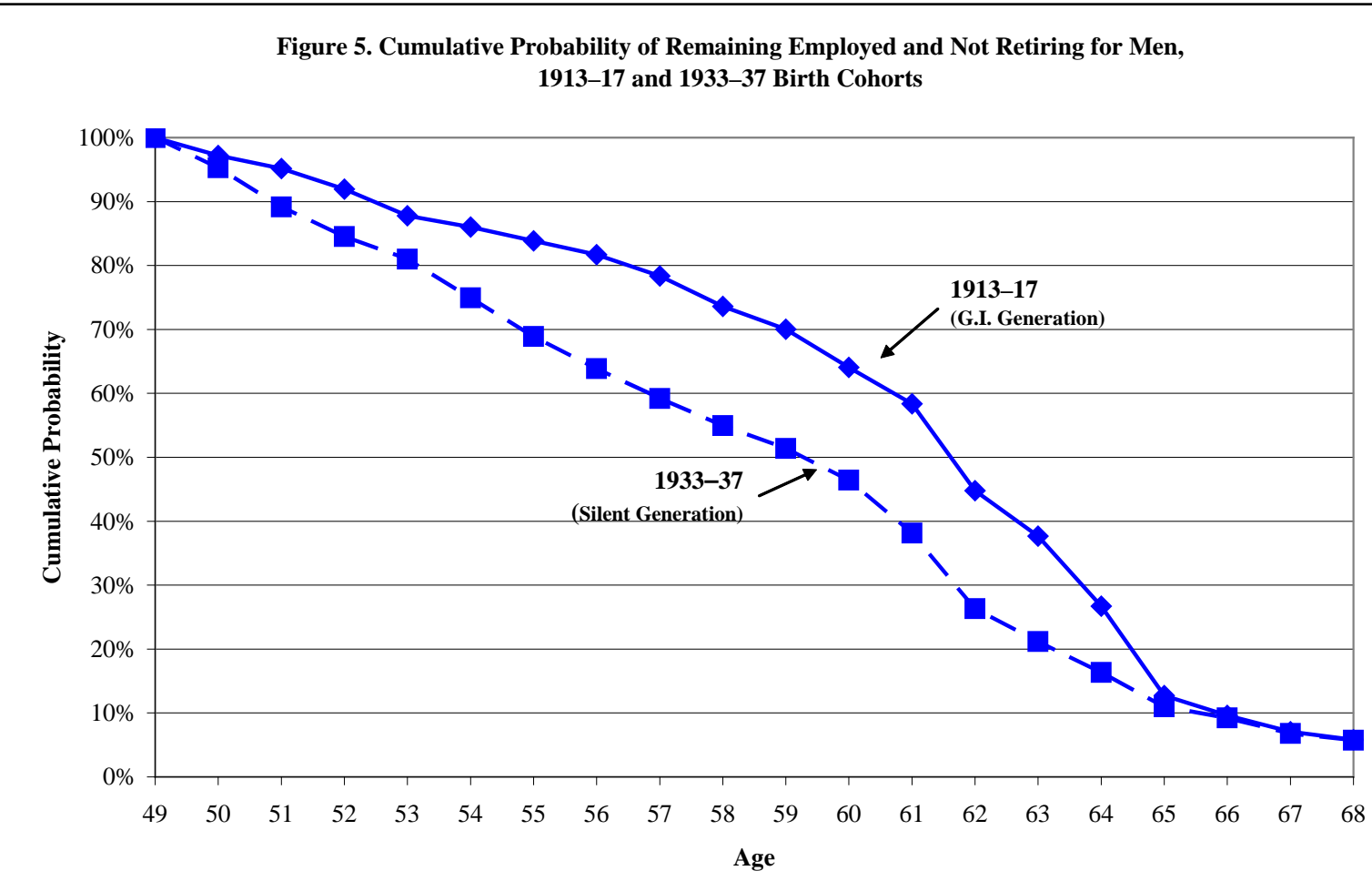

Source: Authors' computations from the SIPP, matched to administrative earnings records.

Note: Sample is restricted to men who were working full-time at age 49 (as defined in the text).

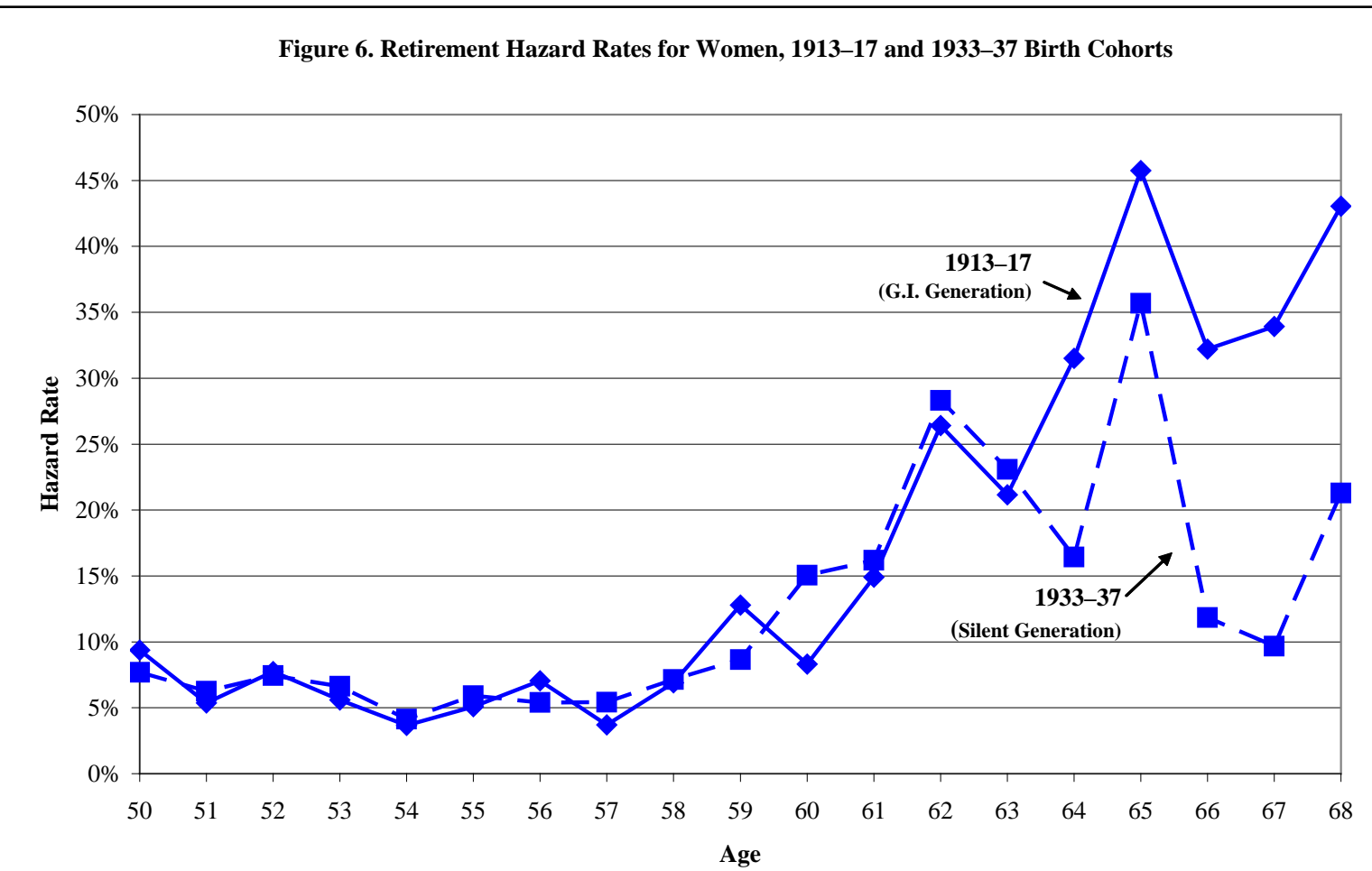

Source: Authors' computations from the SIPP, matched to administrative earnings records.

Note: Sample is restricted to women who were working full-time at age 49 (as defined in the text). Workers are classified as having retired when they experience a significant drop in their earnings (partially retired) or first receive zero earnings in a calendar year (fully retired). 

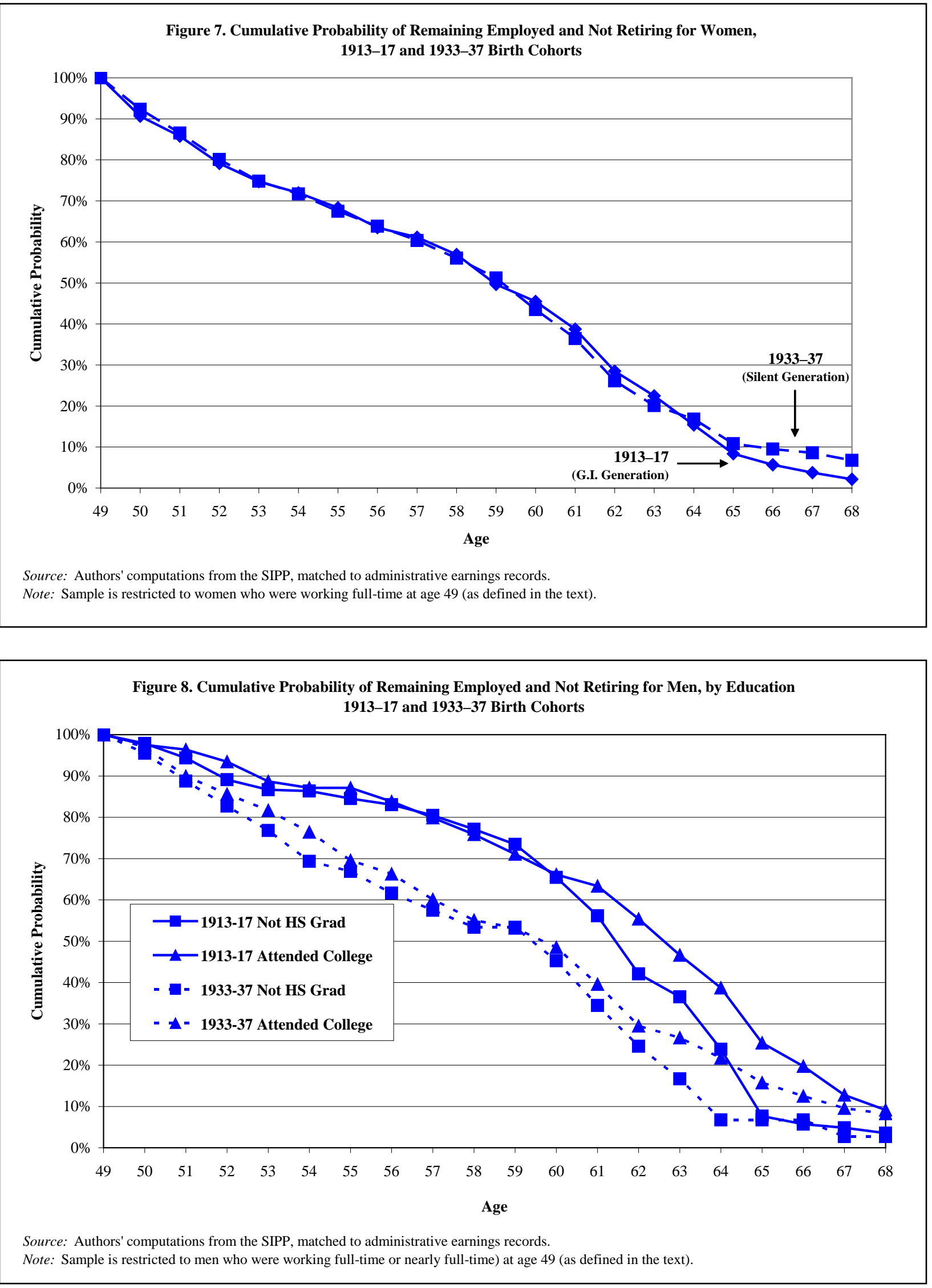

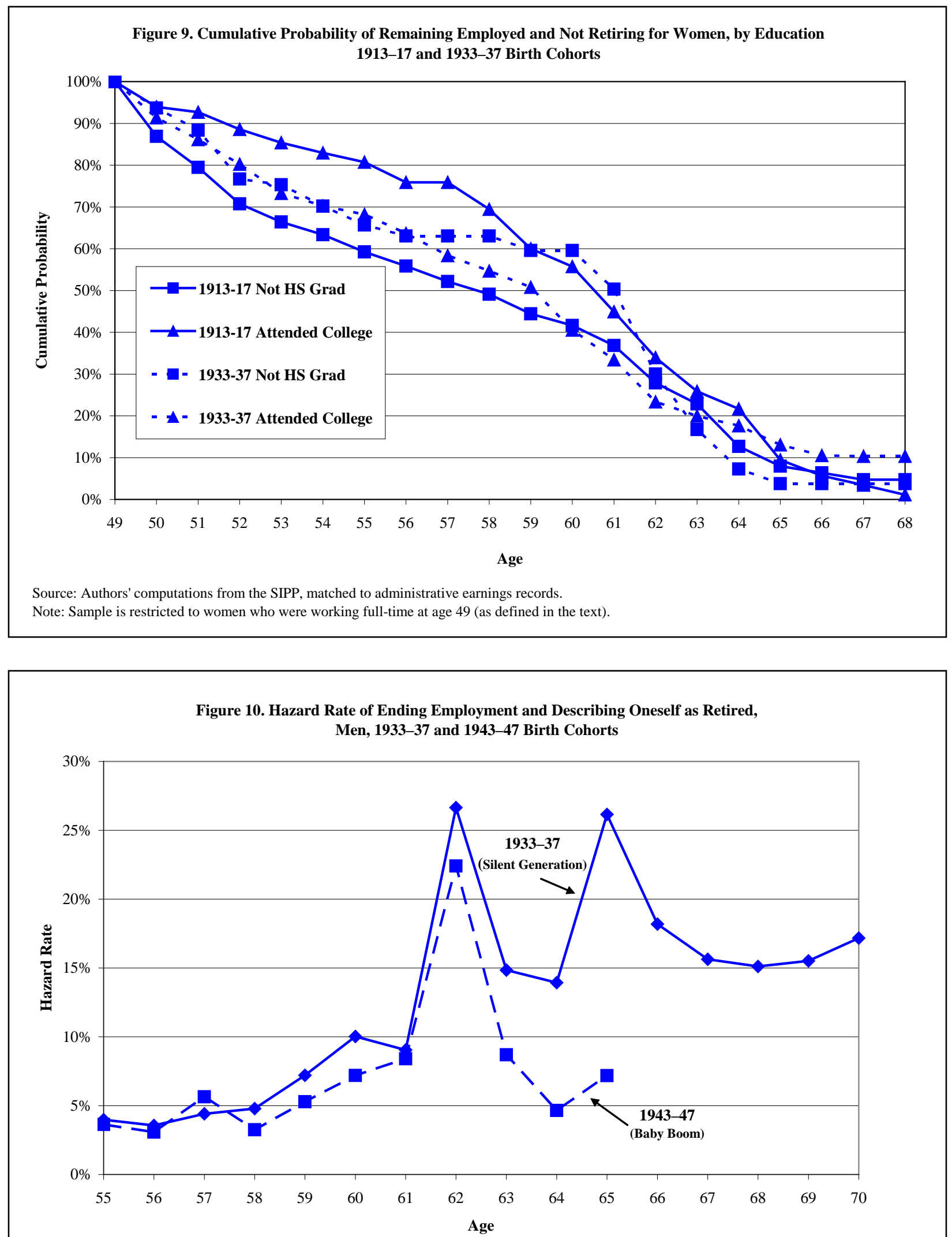

Source: Authors' calculations from the HRS.

Note: Estimates are restricted to men who were working and not retired at age 54. 
Figure 11. Hazard Rate of Ending Employment, Men, 1933-37 and 1943-47 Birth Cohorts

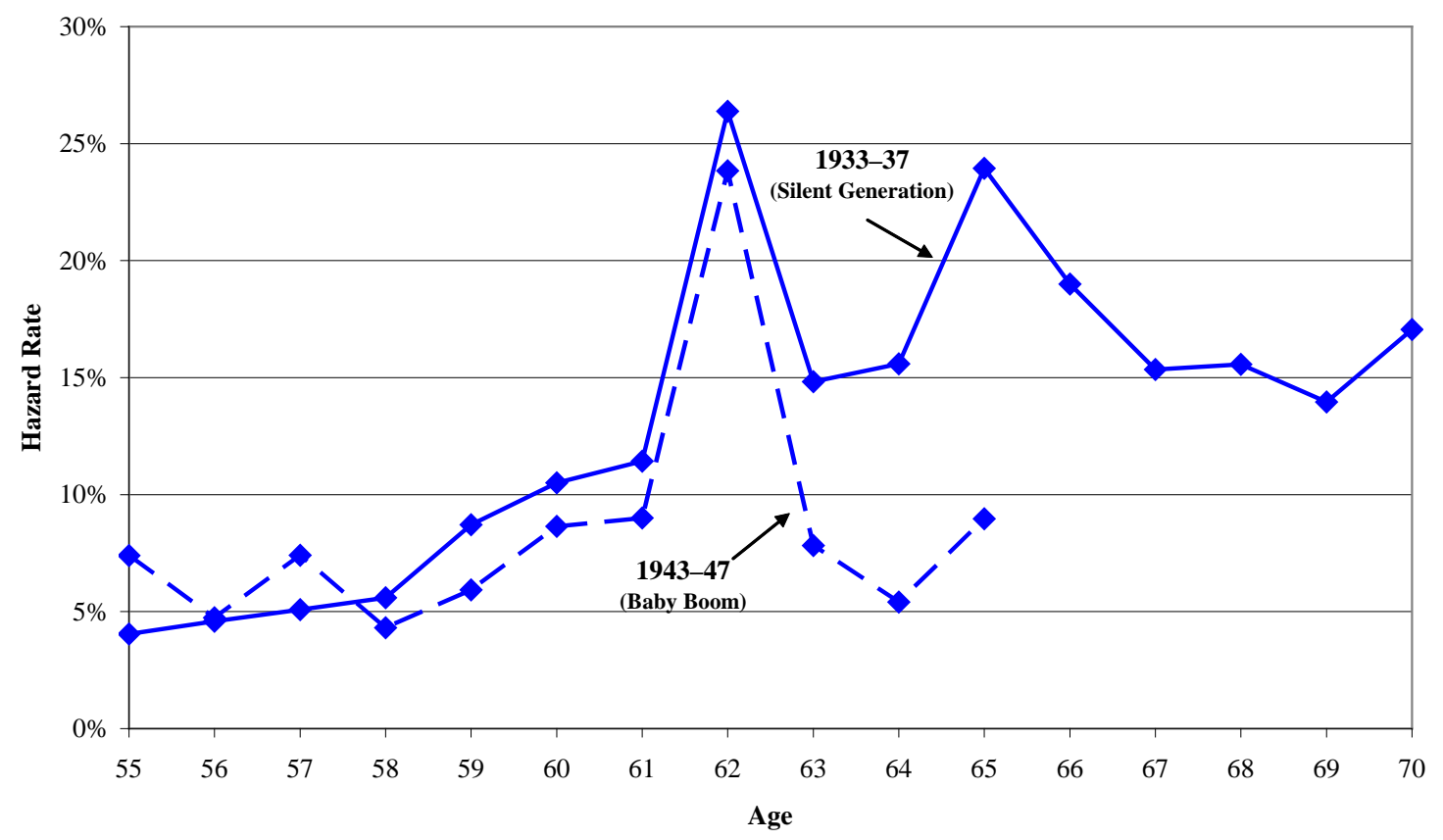

Source: Authors' calculations from the HRS.

Note: Estimates are restricted to men who were employed at age 54.

Figure 12. Hazard Rate of Describing Oneself as Retired, Men, 1933-37 and 1943-47 Birth Cohorts

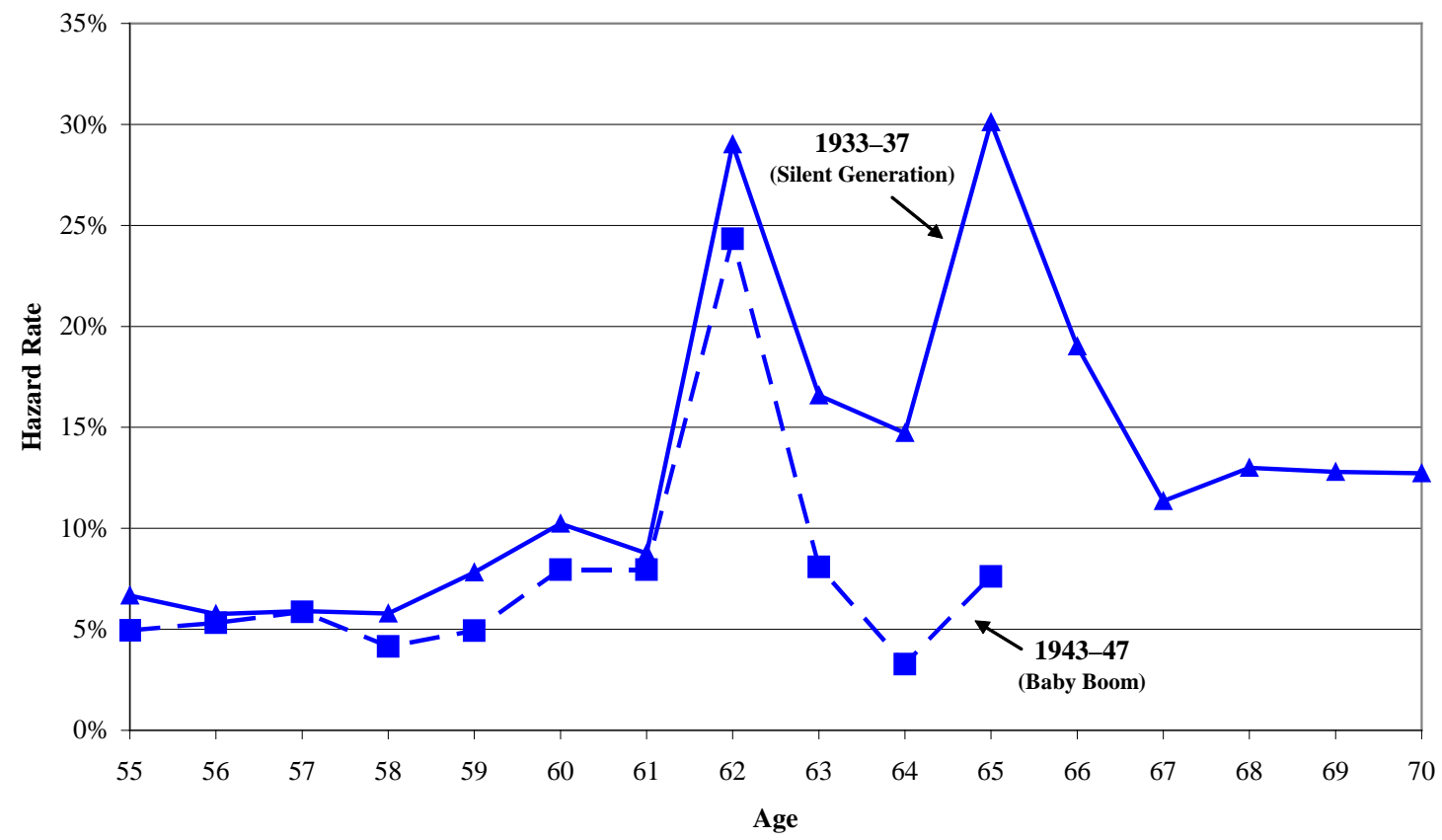

Source: Authors' calculations from the HRS.

Note: Estimates are restricted to men who were not retired at age 54. 
Figure 13. Cumulative Probability of Remaining at Work and Not Yet Described Oneself as Retired, Men, 1933-37 and 1943-47 Birth Cohorts

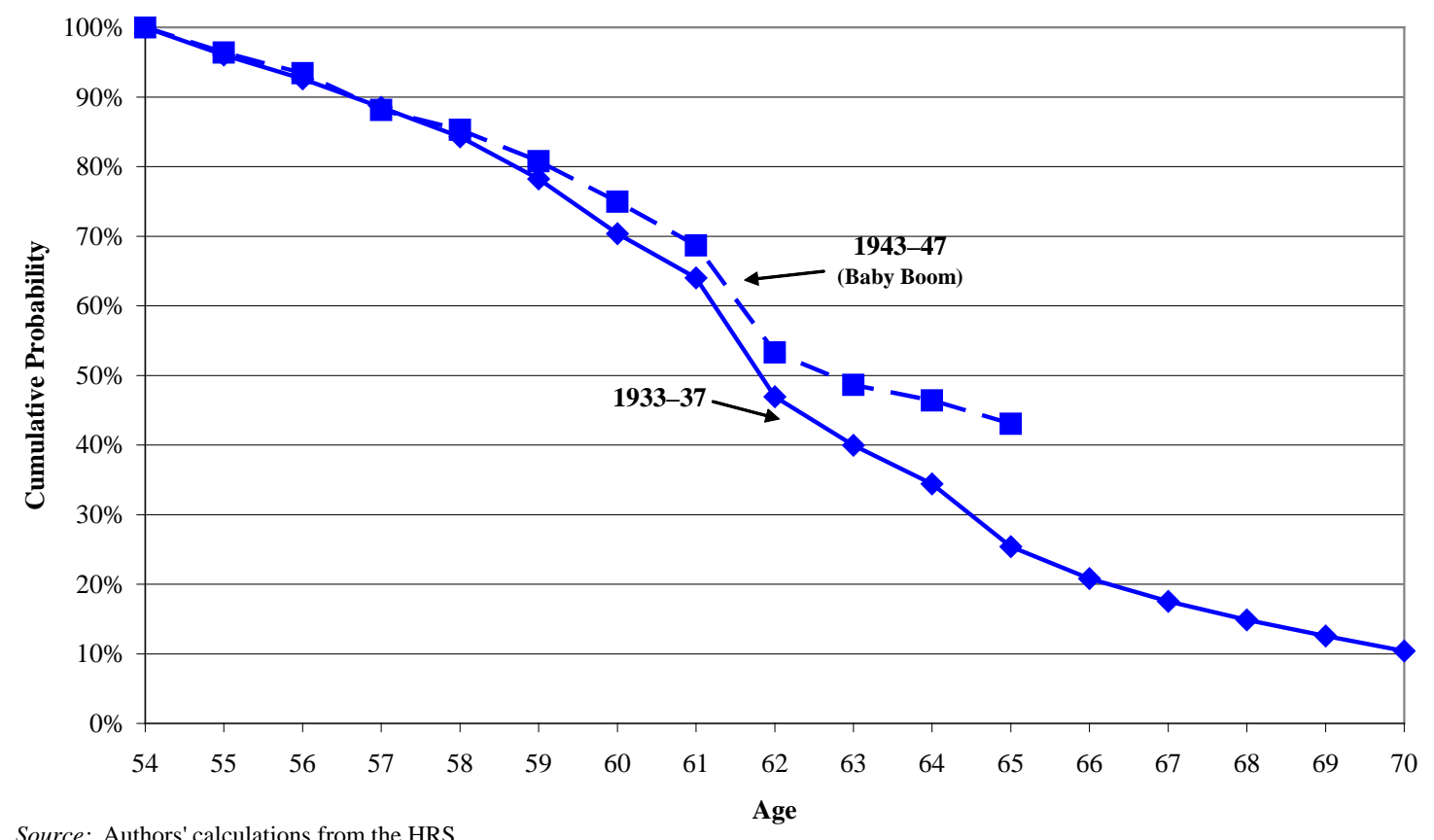

Source: Authors' calculations from the HRS.

Note: Estimates are restricted to men who were working and not retired at age 54.

Figure 14. Cumulative Probability of Remaining at Work, Men, 1933-37 and 1943-47 Birth Cohorts

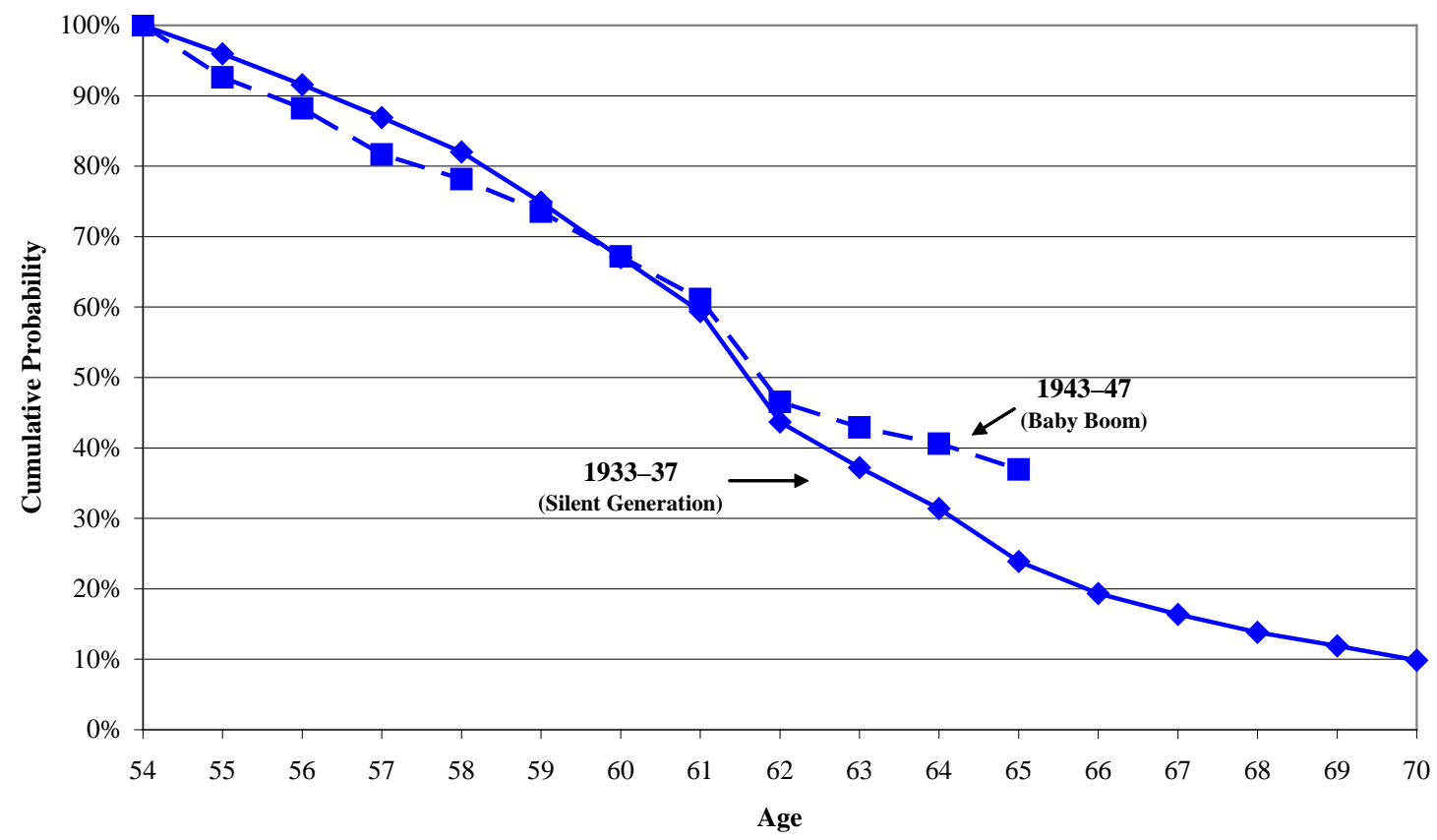

Source: Authors' calculations from the HRS.

Note: Estimates are restricted to men who were employed at age 54. 
Figure 15. Cumulative Probability of Not Yet Describing Oneself as Retired, Men, 1933-37 and 1943-47 Birth Cohorts

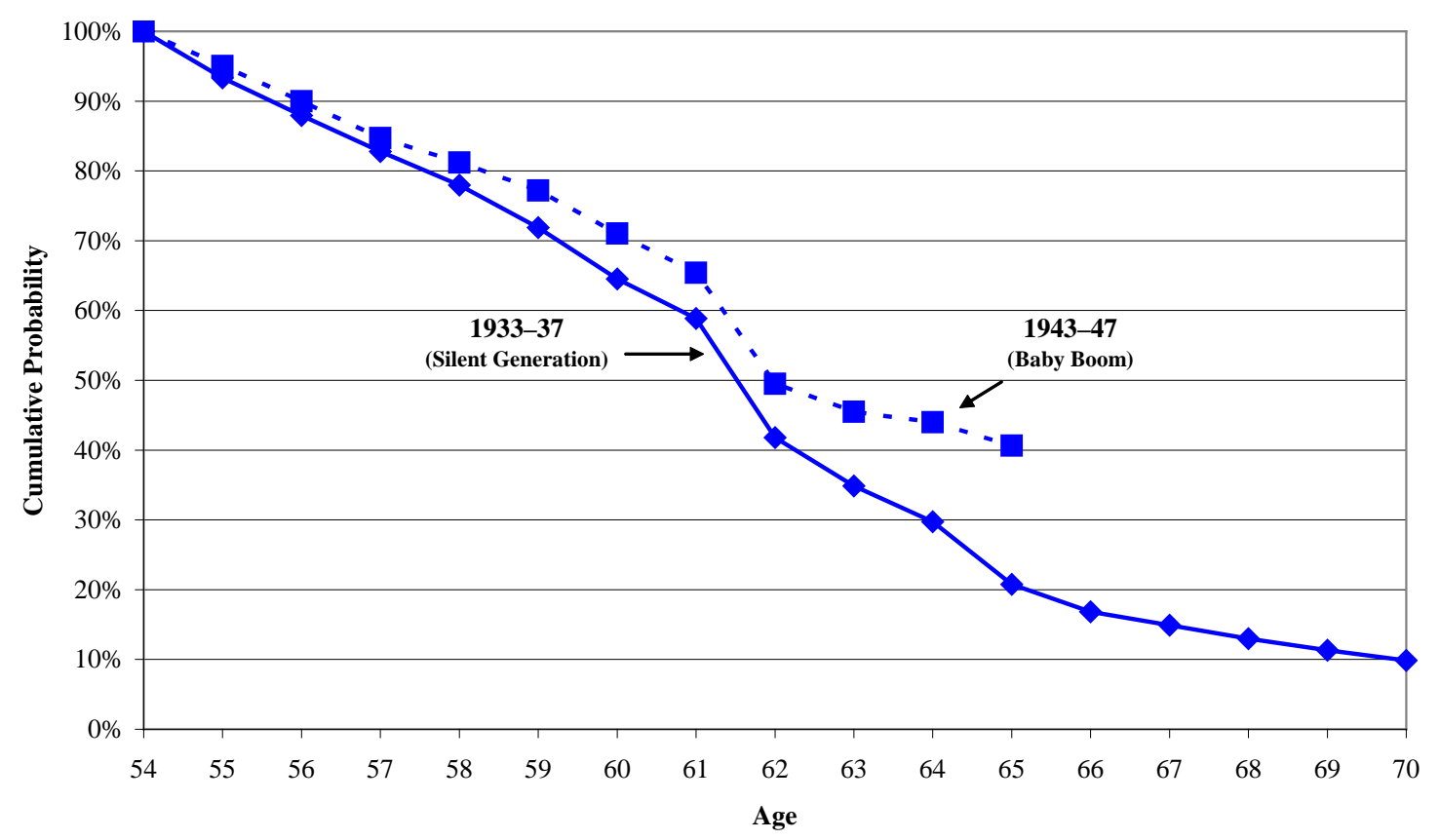

Source: Authors' calculations from the HRS.

Note: Estimates are restricted to men who were not retired at age 54.

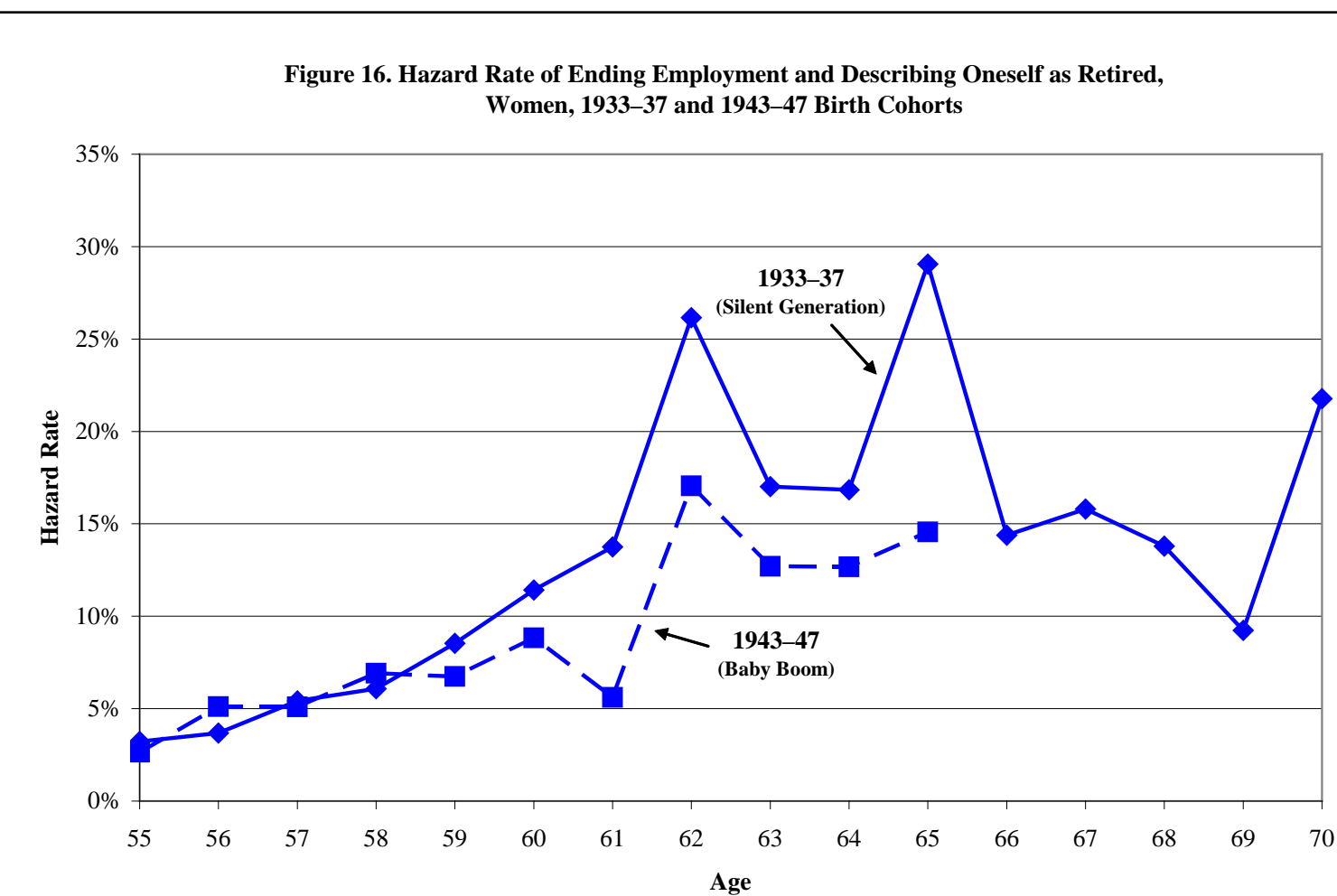

Source: Authors' calculations from the HRS.

Note: Estimates are restricted to women who were not retired at age 54. 
Figure 17. Hazard Rate of Ending Employment, Women, 1933-37 and 1943-47 Birth Cohorts

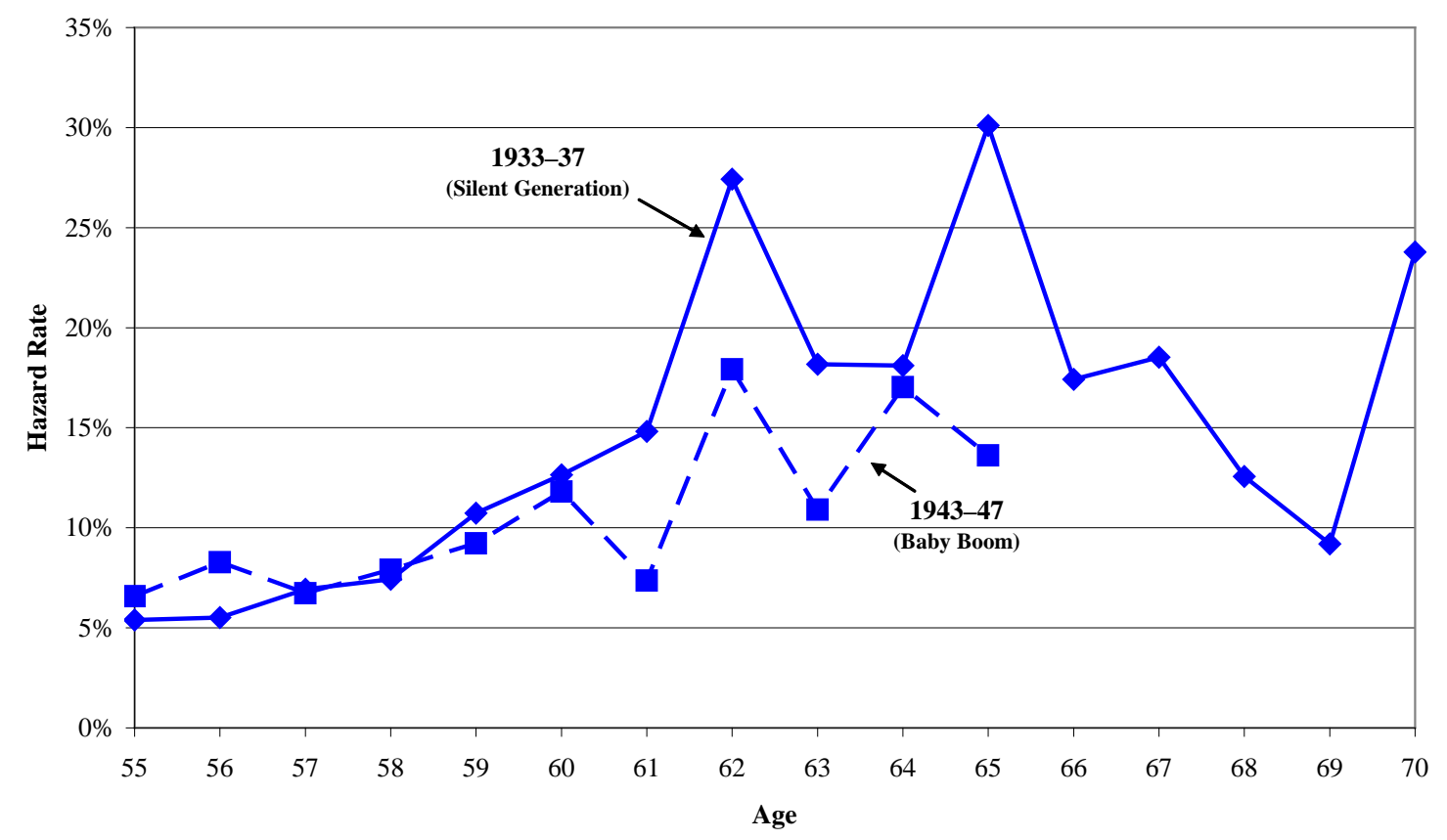

Source: Authors' calculations from the HRS.

Note: Estimates are restricted to women who were employed at age 54 .

Figure 18. Hazard Rate of Describing Oneself as Retired, Women, 1933-37 and 1943-47 Birth Cohorts

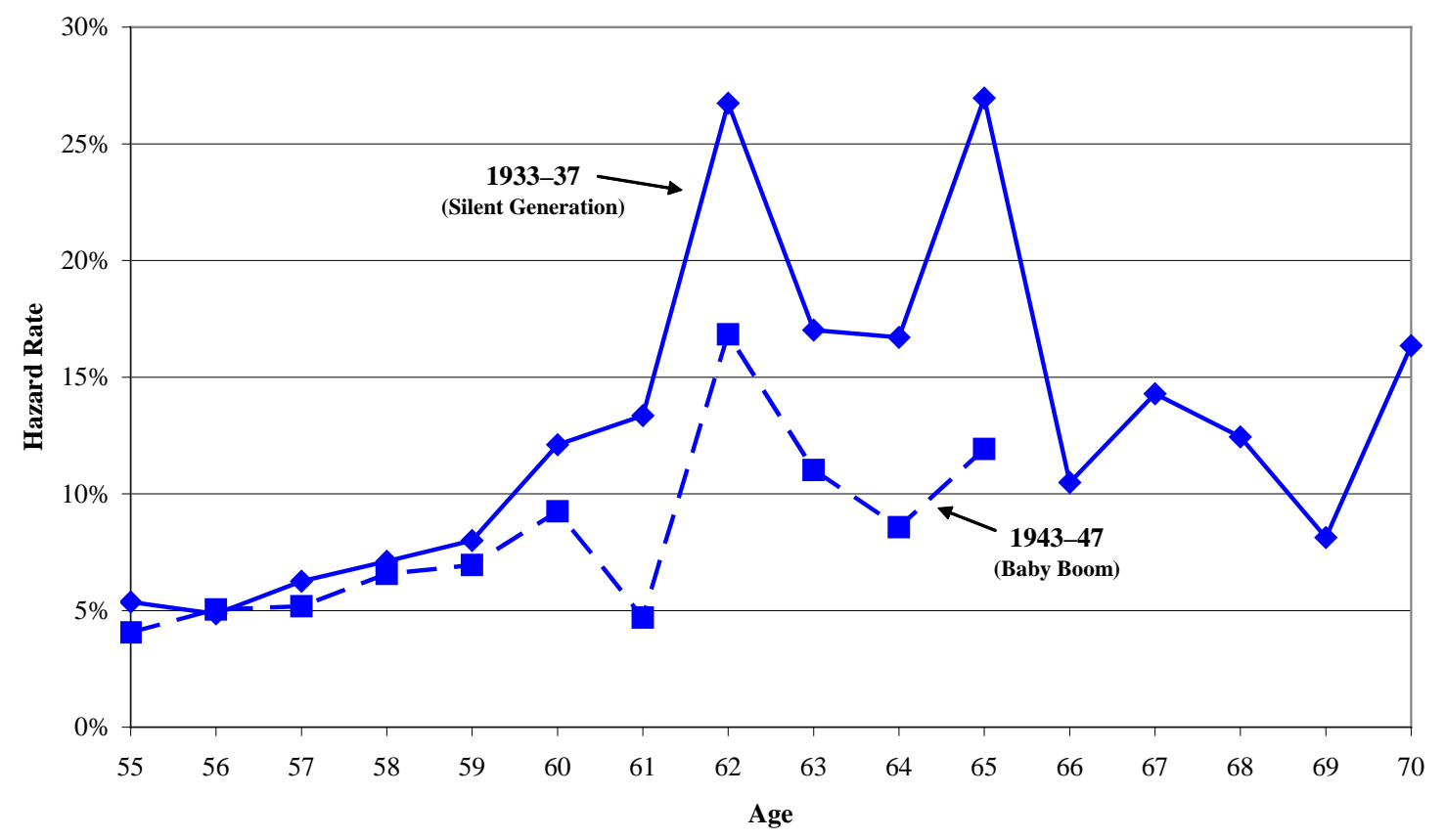

Source: Authors' calculations from the HRS.

Note: Estimates are restricted to women who were not retired at age 54. 
Figure 19. Cumulative Probability of Remaining at Work and Not Yet Describing Oneself as Retired, Women, 1933-37 and 1943-47 Birth Cohorts

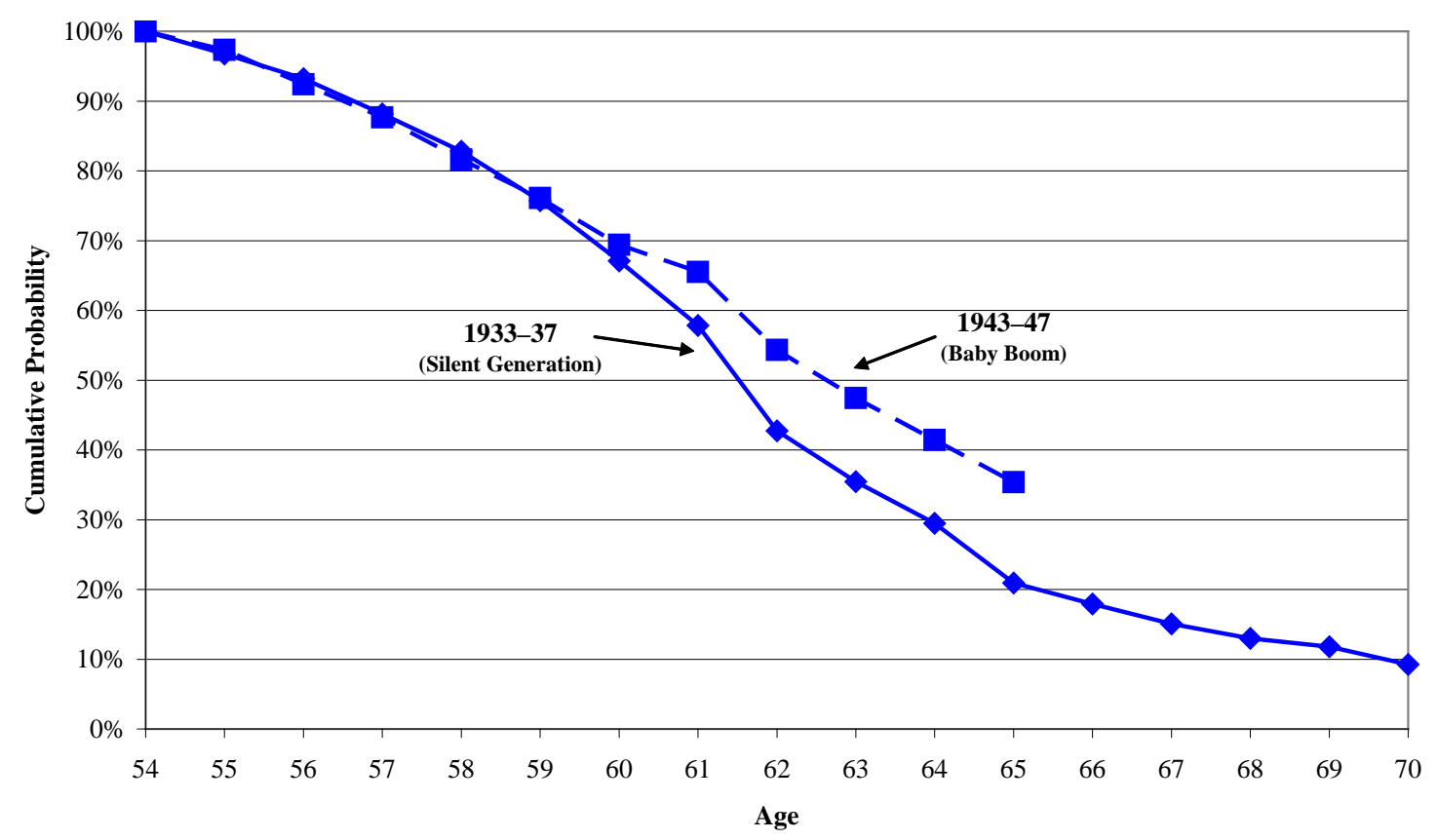

Source: Authors' calculations from the HRS.

Note: Estimates are restricted to women who were working and not retired at age 54.

Figure 20. Cumulative Probability of Remaining at Work, Women, 1933-37 and 1943-47 Birth Cohorts

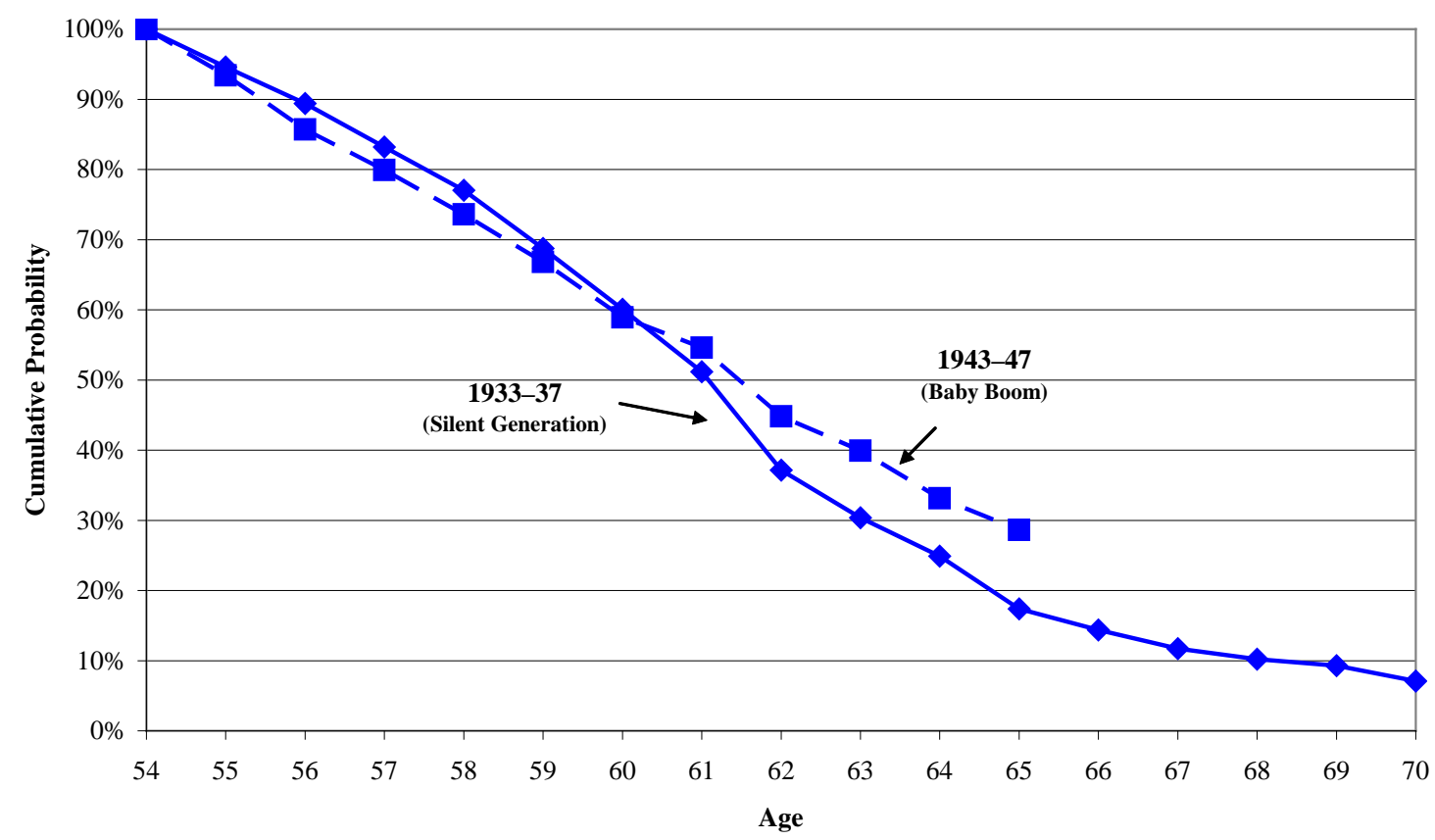

Source: Authors' calculations from the HRS.

Note: Estimates are restricted to women who were employed at age 54. 
Figure 21. Cumulative Probability of Not Yet Descibing Oneself as Retired, Women, 1933-37 and 1943-47 Birth Cohorts

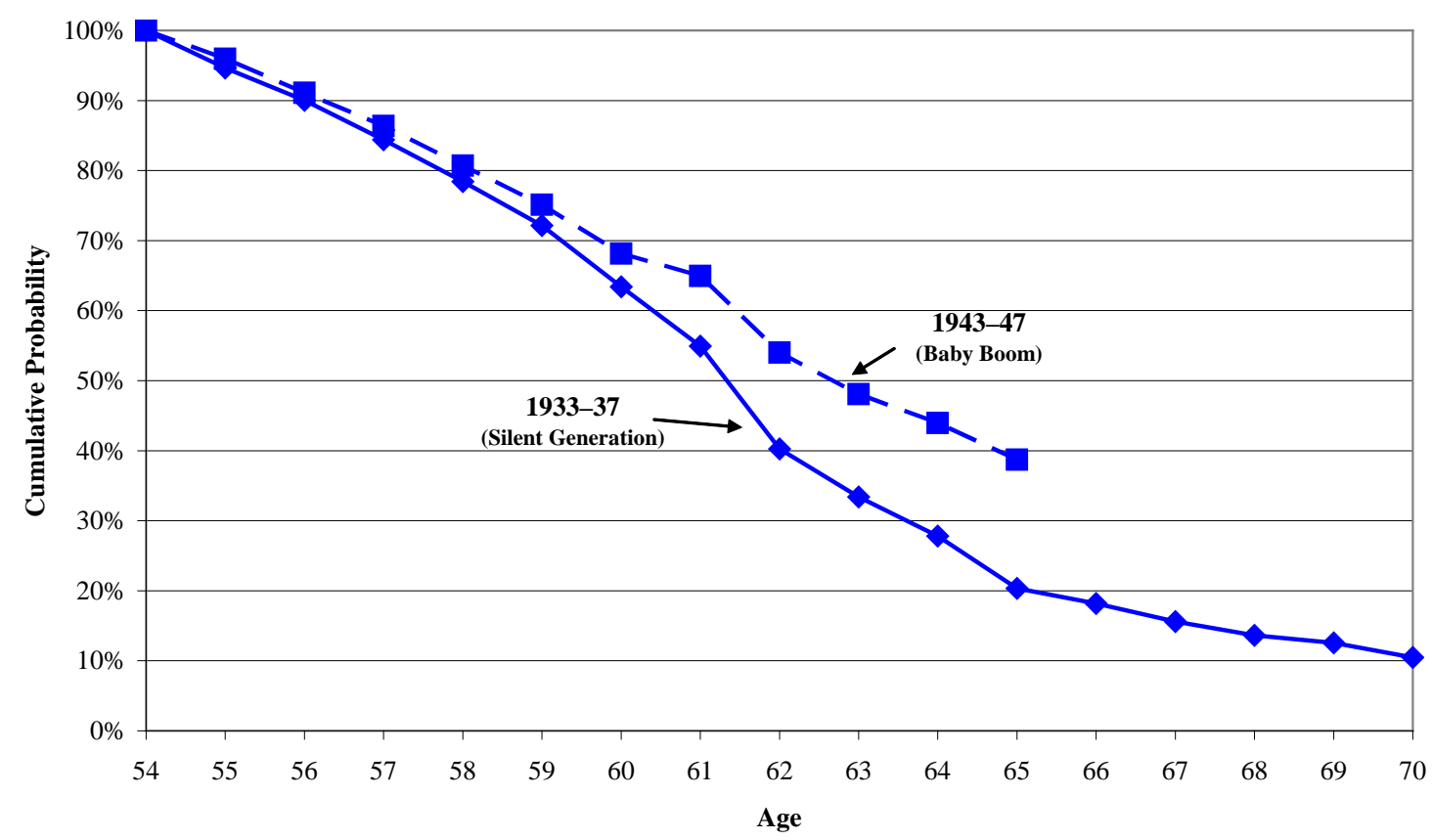

Source: Authors' calculations from the HRS.

Note: Estimates are restricted to women not retired at age 54.

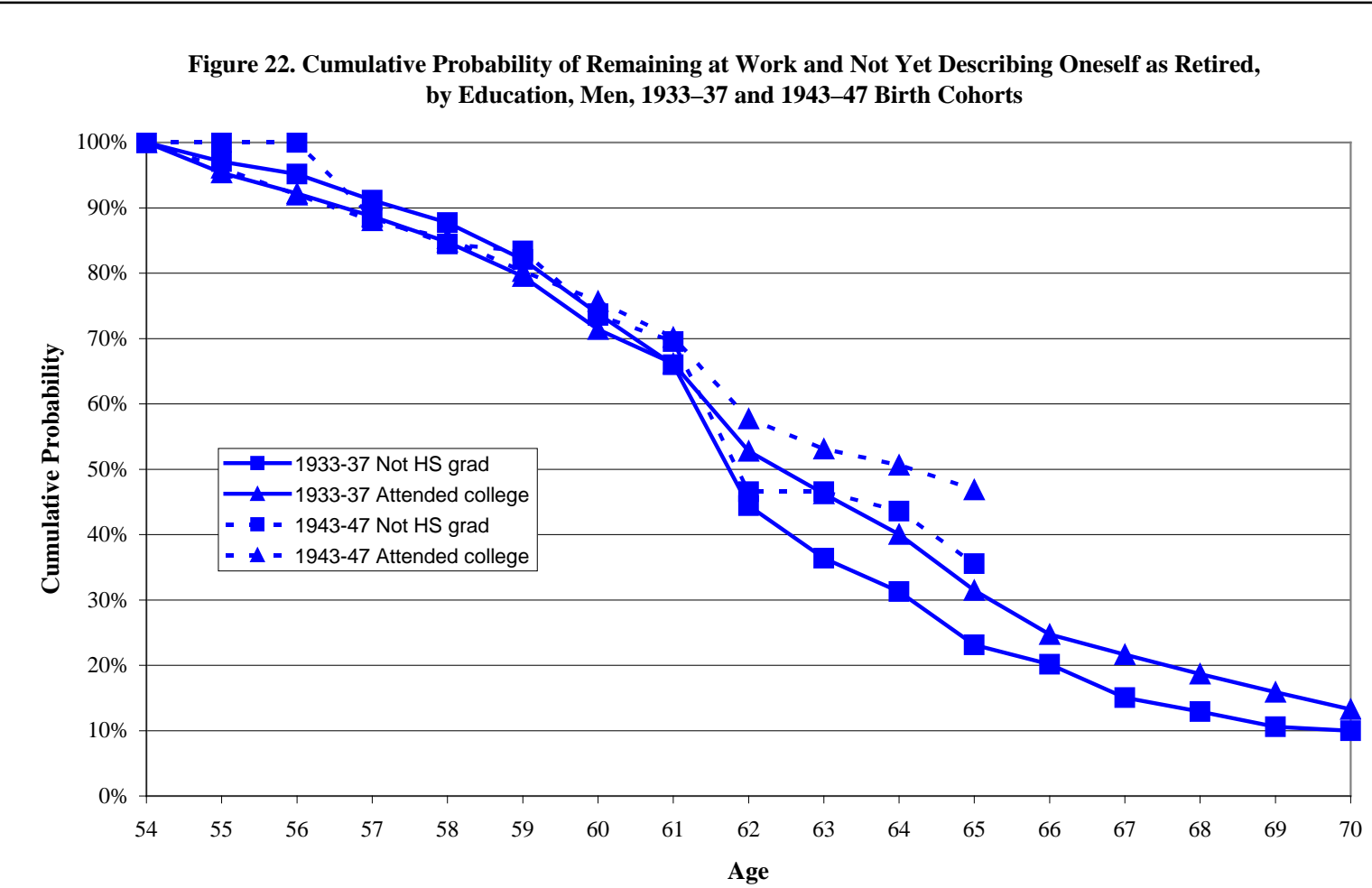

Source: Authors' calculations from the HRS.

Note: Estimates are restricted to men and women who were working and not retired at age 54 . 
Figure 23. Cumulative Probability of Remaining at Work and Not Yet Describing Oneself as Retired, by Education, Women, 1933-37 and 1943-47 Birth Cohorts

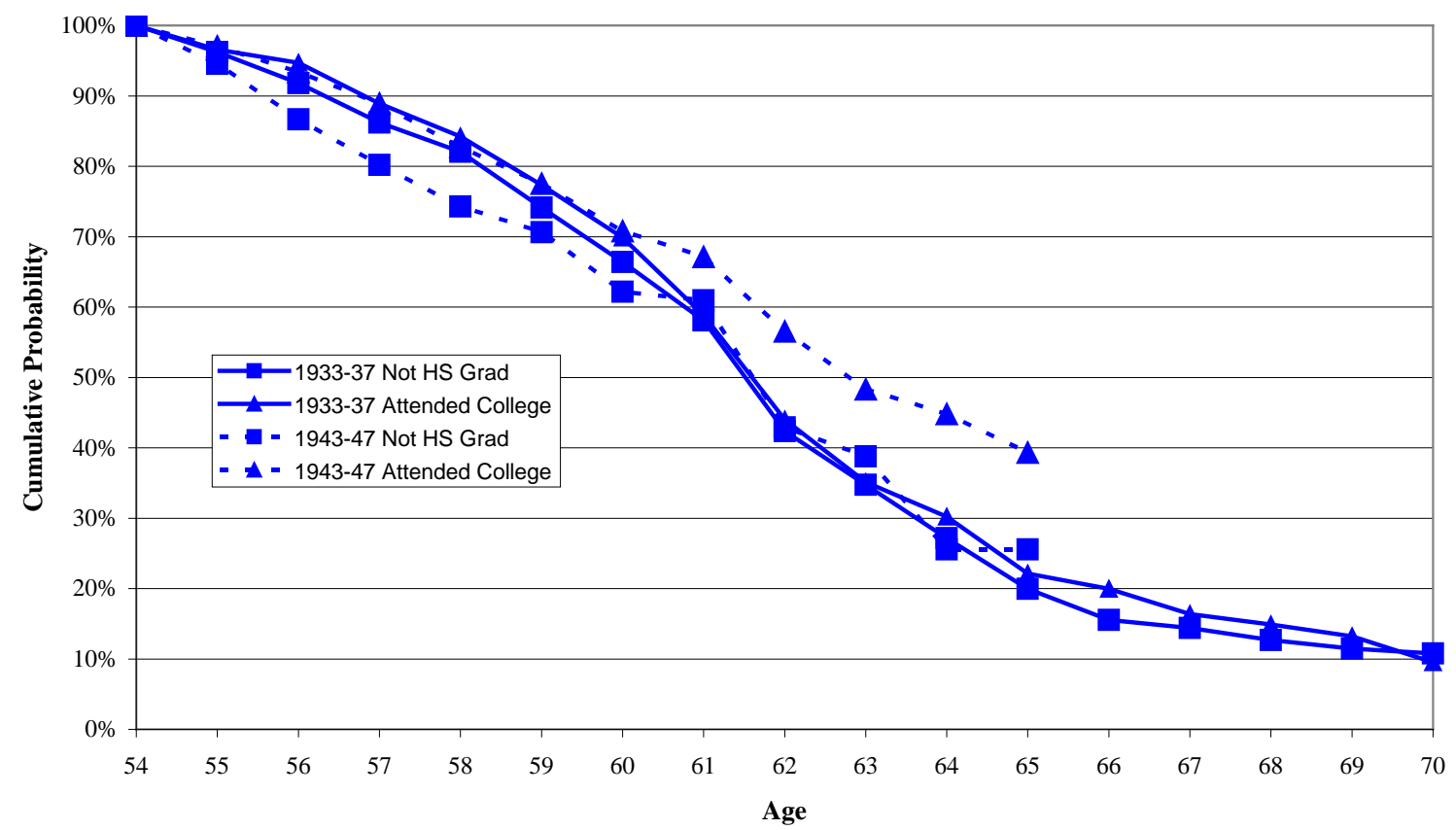

Source: Authors' calculations from the HRS.

Note: Estimates are restricted to men and women who were working and not retired at age 54 . 
Table 1. Differences in Social Security Provisions by Birth Year

\begin{tabular}{|c|c|c|c|c|c|c|c|c|}
\hline & 1913-15 & 1916 & 1917 & 1933 & 1934 & 1935-36 & 1937 & $1943-47$ \\
\hline Year turned age 62 & $1975-77$ & 1978 & 1979 & 1995 & 1996 & 1997-98 & 1999 & 2005-09 \\
\hline Full retirement age (FRA) & 65 & 65 & 65 & 65 & 65 & 65 & 65 & 66 \\
\hline $\begin{array}{l}\text { Share of full retired worker } \\
\text { benefits paid at age } 62\end{array}$ & $80 \%$ & $80 \%$ & $80 \%$ & $80 \%$ & $80 \%$ & $80 \%$ & $80 \%$ & $75 \%$ \\
\hline $\begin{array}{l}\text { Share of full spousal benefit } \\
\text { paid at age } 62\end{array}$ & $75 \%$ & $75 \%$ & $75 \%$ & $75 \%$ & $75 \%$ & $75 \%$ & $75 \%$ & $70 \%$ \\
\hline $\begin{array}{l}\text { Annual delayed retirement } \\
\text { credit for working at age } 66\end{array}$ & $1.0 \%$ & $3.0 \%$ & $3.0 \%$ & $5.5 \%$ & $5.5 \%$ & $6.0 \%$ & $6.5 \%$ & $8.0 \%$ \\
\hline $\begin{array}{l}\text { Benefits if begin collecting at } \\
\text { age } 67 \text {, relative to benefits if } \\
\text { begin collecting at age } 62^{1}\end{array}$ & $127.5 \%$ & $130.0 \%$ & $132.5 \%$ & $138.8 \%$ & $138.8 \%$ & $140.0 \%$ & $141.3 \%$ & $144.0 \%$ \\
\hline $\begin{array}{l}\text { Ages subject to retirement } \\
\text { earnings test }\end{array}$ & $62-70$ & $62-70$ & $62-70$ & $62-66$ & $62-65$ & $62-65$ & $62-65$ & $62-66$ \\
\hline
\end{tabular}

Source: Authors' calculations.

Note:

1. This calculation shows the impact of delayed claiming, under the assumption that beneficiaries do not work once they reach age 62. 
Table 2. Characteristics of Men and Women Working and Not Retired at Age 49, 1913-17 and 1933-37 Birth Cohorts (\%)

\begin{tabular}{|c|c|c|c|c|}
\hline & \multicolumn{2}{|c|}{ Men } & \multicolumn{2}{|c|}{ Women } \\
\hline & $\begin{array}{c}1913-17 \\
\text { (G.I. Gen) } \\
\end{array}$ & $\begin{array}{c}1933-37 \\
\text { (Silent Gen) } \\
\end{array}$ & $\begin{array}{c}1913-17 \\
\text { (G.I. Gen) }\end{array}$ & $\begin{array}{c}1933-37 \\
\text { (Silent Gen) }\end{array}$ \\
\hline \multicolumn{5}{|l|}{ Education } \\
\hline Did not complete high school & 47.1 & 12.9 ** & 38.9 & 10.4 ** \\
\hline High school graduate & 31.1 & 33.6 & 32.6 & 38.8 ** \\
\hline Some college & 18.6 & $53.5^{\star \star}$ & 26.4 & $50.8 * \star$ \\
\hline Missing & 3.2 & 0.0 & 2.1 & 0.0 \\
\hline \multicolumn{5}{|l|}{ Race and ethnicity } \\
\hline Non-Hispanic white & 88.9 & $82.5^{\star *}$ & 91.6 & $84.8^{* *}$ \\
\hline African American & 6.3 & 8.8 & 6.6 & 10.2 ** \\
\hline Hispanic & 4.1 & 5.2 & 1.5 & 3.8 ** \\
\hline Other & 0.8 & $3.5 * \star$ & 0.3 & 1.1 ** \\
\hline \multicolumn{5}{|l|}{ Marital Status at Age 67-71 } \\
\hline Married & 79.9 & 82.4 & 42.7 & 59.6 ** \\
\hline Not married & 20.1 & 17.6 & 57.3 & 40.4 ** \\
\hline \multicolumn{5}{|c|}{ Health-Related Work Limitation at Age 67-71 } \\
\hline Yes & 40.2 & $24.8^{\star \star}$ & 37.5 & 17.4 ** \\
\hline No & 59.8 & $75.2^{* \star}$ & 62.5 & 82.6 ** \\
\hline Observations & 679 & 1,039 & 427 & 844 \\
\hline
\end{tabular}

Source: Authors' estimates from the SIPP, matched to administrative earnings records.

$*$ differs from the value for the earlier cohort $(.05<p<.10)$

** differs significantly from the value for the earlier cohort $(p<.05)$ 
Table 3. Characteristics of Men and Women Employed at Age 54, 1933-37 and 1943-47 Birth Cohorts

\begin{tabular}{|c|c|c|c|c|}
\hline & \multicolumn{2}{|c|}{ Men } & \multicolumn{2}{|c|}{ Women } \\
\hline & $\begin{array}{c}\text { 1933-1937 } \\
\text { (Silent Gen.) }\end{array}$ & $\begin{array}{l}\text { 1943-1947 } \\
\text { (Boomers) } \\
\end{array}$ & $\begin{array}{c}\text { 1933-1937 } \\
\text { (Silent Gen.) }\end{array}$ & $\begin{array}{l}1943-1947 \\
\text { (Boomers) } \\
\end{array}$ \\
\hline \multicolumn{5}{|l|}{ Education (\%) } \\
\hline Did not complete high school & 21.0 & $9.2 * *$ & 19.0 & $8.4 * *$ \\
\hline High school graduate & 35.7 & 33.3 & 44.7 & $34.0 * *$ \\
\hline Some college, less than 4 years & 19.5 & $23.4 *$ & 19.2 & $30.3 * *$ \\
\hline Bachelor's degree or more & 23.8 & $34.1 * *$ & 17.1 & $27.4 * *$ \\
\hline \multicolumn{5}{|l|}{ Race (\%) } \\
\hline Non-Hispanic white & 83.1 & 82.2 & 82.6 & 81.7 \\
\hline African American & 8.8 & 7.8 & 10.7 & 9.1 \\
\hline Hispanic & 5.8 & 7.1 & 4.7 & $6.5 *$ \\
\hline Other & 2.3 & 2.7 & 2.1 & 2.7 \\
\hline Married (\%) & 85.1 & 83.8 & 67.2 & 66.9 \\
\hline Health-related work limitation (\%) & 11.0 & $6.2 * *$ & 9.1 & 10.5 \\
\hline Fair or poor health (\%) & 13.1 & $9.9 * *$ & 13.4 & 14.1 \\
\hline Access to retiree health insurance $(\%)$ & 46.8 & $34.5 * *$ & 31.6 & $26.9 * *$ \\
\hline \multicolumn{5}{|l|}{ Pension coverage $(\%)$} \\
\hline Defined benefit plan & 37.9 & 40.1 & 33.6 & $29.2 *$ \\
\hline Defined contribution plan only & 31.5 & 35.0 & 25.5 & $33.4 * *$ \\
\hline None & 30.5 & $24.8 * *$ & 40.8 & 37.4 \\
\hline \multicolumn{5}{|l|}{ Earnings (\$2008) } \\
\hline Mean & 58,379 & 60,782 & 29,203 & $37,247 * *$ \\
\hline Median & 47,424 & 51,060 & 25,293 & $30,393 * *$ \\
\hline \multicolumn{5}{|c|}{ Household wealth, excluding housing (\$2008) } \\
\hline Mean & 302,553 & 279,388 & 232,186 & 240,841 \\
\hline Median & 88,524 & 98,473 & 69,871 & 76,590 \\
\hline Zero or Negative Wealth (\%) & 5.9 & 4.9 & 7.9 & 7.8 \\
\hline $\mathbf{N}$ & 1519 & 652 & 1309 & 853 \\
\hline
\end{tabular}

Source: Authors' estimates from 1992-2008 waves of the Health and Retirement Study (HRS).

Notes: The sample was restricted to noninstitutionalized adults age 55 to 59 in 1992 and age 55 to 59 in 2002 who were working at baseline and were observed for six years or until they stopped working. Characteristics were measured at survey baseline.

$*$ differs from the value for the earlier cohort $(.05<p<.10)$

$* *$ differs significantly from the value for the earlier cohort $(p<.05)$ 
Table 4. Estimated Marginal Effects on the Likelihood of Retirement for Men in the 1933-37 and 1943-47 Birth Cohorts, Under Alternative Retirement Definitions

\begin{tabular}{|c|c|c|c|c|c|c|}
\hline & \multicolumn{2}{|c|}{ Stop Work } & \multicolumn{2}{|c|}{$\begin{array}{c}\text { Describe Oneself as } \\
\text { Retired }\end{array}$} & \multicolumn{2}{|c|}{$\begin{array}{c}\text { Stop Work and } \\
\text { Retired }\end{array}$} \\
\hline & $\begin{array}{l}\text { 1933-37 } \\
\text { (Silent G.) } \\
\end{array}$ & $\begin{array}{l}\text { 1943-47 } \\
\text { (Boomers) } \\
\end{array}$ & $\begin{array}{l}\text { 1933-37 } \\
\text { (Silent G.) } \\
\end{array}$ & $\begin{array}{l}\text { 1943-47 } \\
\text { (Boomers) } \\
\end{array}$ & $\begin{array}{l}\text { 1933-37 } \\
\text { (Silent G.) } \\
\end{array}$ & $\begin{array}{l}\text { 1943-47 } \\
\text { (Boomers) }\end{array}$ \\
\hline \multicolumn{7}{|l|}{ Education } \\
\hline Did not complete high school & $\begin{array}{l}0.011 \\
(0.018)\end{array}$ & $\begin{array}{l}0.039 \\
(0.036)\end{array}$ & $\begin{array}{l}-0.005 \\
(0.021)\end{array}$ & $\begin{array}{l}0.091^{*} \\
(0.050)\end{array}$ & $\begin{array}{l}-0.008 \\
(0.016)\end{array}$ & $\begin{array}{l}0.054 \\
(0.040)\end{array}$ \\
\hline [Reference: High school graduate] & - & - & - & - & - & - \\
\hline Some college, fewer than 4 years & $\begin{array}{l}0.006 \\
(0.019)\end{array}$ & $\begin{array}{l}0.012 \\
(0.026)\end{array}$ & $\begin{array}{l}0.000 \\
(0.022)\end{array}$ & $\begin{array}{l}-0.006 \\
(0.029)\end{array}$ & $\begin{array}{l}0.005 \\
(0.017)\end{array}$ & $\begin{array}{l}-0.006 \\
(0.024)\end{array}$ \\
\hline Bachelor's degree or more & $\begin{array}{l}-0.073^{* *} \\
(0.016)\end{array}$ & $\begin{array}{l}-0.009 \\
(0.025)\end{array}$ & $\begin{array}{l}-0.081^{* *} \\
(0.018)\end{array}$ & $\begin{array}{l}-0.047 * \\
(0.027)\end{array}$ & $\begin{array}{l}-0.058 * * \\
(0.014)\end{array}$ & $\begin{array}{l}-0.027 \\
(0.022)\end{array}$ \\
\hline \multicolumn{7}{|l|}{ Race } \\
\hline African American & $\begin{array}{l}-0.027 \\
(0.020)\end{array}$ & $\begin{array}{l}0.017 \\
(0.035)\end{array}$ & $\begin{array}{l}-0.015 \\
(0.026)\end{array}$ & $\begin{array}{l}0.063 \\
(0.051)\end{array}$ & $\begin{array}{l}-0.026 \\
(0.018)\end{array}$ & $\begin{array}{l}0.009 \\
(0.033)\end{array}$ \\
\hline Hispanic & $\begin{array}{l}-0.032 \\
(0.025)\end{array}$ & $\begin{array}{l}-0.068 * * \\
(0.026)\end{array}$ & $\begin{array}{l}-0.047 * \\
(0.028)\end{array}$ & $\begin{array}{l}-0.092 * * \\
(0.028)\end{array}$ & $\begin{array}{l}-0.037^{*} \\
(0.020)\end{array}$ & $\begin{array}{l}-0.087^{* *} \\
(0.021)\end{array}$ \\
\hline Other & $\begin{array}{l}-0.034 \\
(0.039)\end{array}$ & $\begin{array}{l}-0.034 \\
(0.048)\end{array}$ & $\begin{array}{l}-0.044 \\
(0.041)\end{array}$ & $\begin{array}{l}-0.088 * \\
(0.049)\end{array}$ & $\begin{array}{l}-0.017 \\
(0.034)\end{array}$ & $\begin{array}{l}-0.061 \\
(0.043)\end{array}$ \\
\hline [Reference: Non-Hispanic white] & - & - & - & - & - & - \\
\hline Married & $\begin{array}{l}-0.062 * * \\
(0.024)\end{array}$ & $\begin{array}{l}0.000 \\
(0.027)\end{array}$ & $\begin{array}{l}-0.043 \\
(0.027)\end{array}$ & $\begin{array}{l}0.030 \\
(0.028)\end{array}$ & $\begin{array}{l}-0.024 \\
(0.020)\end{array}$ & $\begin{array}{l}0.032 \\
(0.022)\end{array}$ \\
\hline Health-related work limitation & $\begin{array}{l}0.094^{* *} \\
(0.028)\end{array}$ & $\begin{array}{l}0.090 * * \\
(0.039)\end{array}$ & $\begin{array}{l}0.075 * * \\
(0.031)\end{array}$ & $\begin{array}{l}0.031 \\
(0.040)\end{array}$ & $\begin{array}{l}0.048 * * \\
(0.023)\end{array}$ & $\begin{array}{l}0.033 \\
(0.032)\end{array}$ \\
\hline Fair or poor health & $\begin{array}{l}0.078 * * \\
(0.023)\end{array}$ & $\begin{array}{l}0.069 * * \\
(0.034)\end{array}$ & $\begin{array}{l}0.075^{* *} \\
(0.027)\end{array}$ & $\begin{array}{l}0.149 * * \\
(0.048)\end{array}$ & $\begin{array}{l}0.052^{* *} \\
(0.021)\end{array}$ & $\begin{array}{l}0.116^{* *} \\
(0.040)\end{array}$ \\
\hline Retiree health insurance offered & $\begin{array}{l}0.060 * * \\
(0.016)\end{array}$ & $\begin{array}{l}0.050^{* *} \\
(0.021)\end{array}$ & $\begin{array}{l}0.048 * * \\
(0.018)\end{array}$ & $\begin{array}{l}0.019 \\
(0.023)\end{array}$ & $\begin{array}{l}0.039 * * \\
(0.014)\end{array}$ & $\begin{array}{l}0.031 \\
(0.020)\end{array}$ \\
\hline \multicolumn{7}{|l|}{ Pension coverage } \\
\hline Defined benefit plan & $\begin{array}{l}0.084^{* *} \\
(0.018)\end{array}$ & $\begin{array}{l}0.054^{* *} \\
(0.022)\end{array}$ & $\begin{array}{l}0.105^{* *} \\
(0.020)\end{array}$ & $\begin{array}{l}0.086 * * \\
(0.026)\end{array}$ & $\begin{array}{l}0.085^{* *} \\
(0.016)\end{array}$ & $\begin{array}{l}0.079 * * \\
(0.021)\end{array}$ \\
\hline Defined contribution plan only & $\begin{array}{l}-0.020 \\
(0.015)\end{array}$ & $\begin{array}{l}-0.021 \\
(0.021)\end{array}$ & $\begin{array}{l}-0.012 \\
(0.017)\end{array}$ & $\begin{array}{l}-0.024 \\
(0.024)\end{array}$ & $\begin{array}{l}-0.012 \\
(0.013)\end{array}$ & $\begin{array}{l}-0.029 \\
(0.019)\end{array}$ \\
\hline [Reference: None] & - & - & - & - & - & - \\
\hline $\begin{array}{l}\text { Log of previous wave's earnings } \\
\text { (\$2008) }\end{array}$ & $\begin{array}{l}-0.003 \\
(0.002)\end{array}$ & $\begin{array}{l}-0.000 \\
(0.003)\end{array}$ & $\begin{array}{l}-0.006 * * \\
(0.002)\end{array}$ & $\begin{array}{l}-0.001 \\
(0.003)\end{array}$ & $\begin{array}{l}-0.003^{*} \\
(0.002)\end{array}$ & $\begin{array}{l}-0.001 \\
(0.002)\end{array}$ \\
\hline
\end{tabular}

(continued) 
Table 4. (continued)

\begin{tabular}{|c|c|c|c|c|c|c|}
\hline & \multicolumn{2}{|c|}{ Stop Work } & \multicolumn{2}{|c|}{$\begin{array}{c}\text { Describe Oneself as } \\
\text { Retired } \\
\end{array}$} & \multicolumn{2}{|c|}{$\begin{array}{c}\text { Stop Work and } \\
\text { Retired }\end{array}$} \\
\hline & $\begin{array}{l}\text { 1933-37 } \\
\text { (Silent G.) }\end{array}$ & $\begin{array}{l}\text { 1943-47 } \\
\text { (Boomers) } \\
\end{array}$ & $\begin{array}{l}\text { 1933-37 } \\
\text { (Silent G.) }\end{array}$ & $\begin{array}{l}\text { 1943-47 } \\
\text { (Boomers) }\end{array}$ & $\begin{array}{l}\text { 1933-37 } \\
\text { (Silent G.) }\end{array}$ & $\begin{array}{l}\text { 1943-47 } \\
\text { (Boomers) }\end{array}$ \\
\hline $\begin{array}{l}\text { Log of previous wave's household } \\
\text { wealth (excluding housing) (\$2008) }\end{array}$ & $\begin{array}{l}0.015 * * \\
(0.004)\end{array}$ & $\begin{array}{l}-0.006 \\
(0.006)\end{array}$ & $\begin{array}{l}0.020 * * \\
(0.005)\end{array}$ & $\begin{array}{l}0.006 \\
(0.007)\end{array}$ & $\begin{array}{l}0.016 * * \\
(0.004)\end{array}$ & $\begin{array}{l}0.001 \\
(0.006)\end{array}$ \\
\hline $\begin{array}{l}\text { Zero or negative household wealth } \\
\text { (excluding housing) in previous year }\end{array}$ & $\begin{array}{l}0.324^{* *} \\
(0.089)\end{array}$ & $\begin{array}{l}-0.037 \\
(0.060)\end{array}$ & $\begin{array}{l}0.288 * * \\
(0.102)\end{array}$ & $\begin{array}{l}0.035 \\
(0.101)\end{array}$ & $\begin{array}{l}0.278 * * \\
(0.096)\end{array}$ & $\begin{array}{l}0.009 \\
(0.072)\end{array}$ \\
\hline \multicolumn{7}{|l|}{ Age } \\
\hline [Reference: 55] & - & - & - & - & - & - \\
\hline 56 & $\begin{array}{l}-0.069 * * \\
(0.027)\end{array}$ & $\begin{array}{l}0.003 \\
(0.048)\end{array}$ & $\begin{array}{l}-0.038 \\
(0.039)\end{array}$ & $\begin{array}{l}0.001 \\
(0.056)\end{array}$ & $\begin{array}{l}-0.051^{*} \\
(0.027)\end{array}$ & $\begin{array}{l}0.009 \\
(0.052)\end{array}$ \\
\hline 57 & $\begin{array}{l}-0.006 \\
(0.031)\end{array}$ & $\begin{array}{l}-0.032 \\
(0.038)\end{array}$ & $\begin{array}{l}0.027 \\
(0.041)\end{array}$ & $\begin{array}{l}-0.007 \\
(0.047)\end{array}$ & $\begin{array}{l}0.016 \\
(0.033)\end{array}$ & $\begin{array}{l}0.022 \\
(0.047)\end{array}$ \\
\hline 58 & $\begin{array}{l}0.030 \\
(0.033)\end{array}$ & $\begin{array}{l}-0.008 \\
(0.042)\end{array}$ & $\begin{array}{l}0.072 * \\
(0.043)\end{array}$ & $\begin{array}{l}-0.017 \\
(0.047)\end{array}$ & $\begin{array}{l}0.046 \\
(0.035)\end{array}$ & $\begin{array}{l}0.030 \\
(0.050)\end{array}$ \\
\hline 59 & $\begin{array}{l}0.070 * * \\
(0.034)\end{array}$ & $\begin{array}{l}0.042 \\
(0.043)\end{array}$ & $\begin{array}{l}0.115^{* *} \\
(0.044)\end{array}$ & $\begin{array}{l}0.045 \\
(0.050)\end{array}$ & $\begin{array}{l}0.096 * * \\
(0.037)\end{array}$ & $\begin{array}{l}0.073 \\
(0.050)\end{array}$ \\
\hline 60 & $\begin{array}{l}0.225 * * \\
(0.046)\end{array}$ & $\begin{array}{l}0.147^{* *} \\
(0.059)\end{array}$ & $\begin{array}{l}0.299 * * \\
(0.055)\end{array}$ & $\begin{array}{l}0.149 * * \\
(0.068)\end{array}$ & $\begin{array}{l}0.247^{* *} \\
(0.052)\end{array}$ & $\begin{array}{l}0.163 * * \\
(0.068)\end{array}$ \\
\hline 61 & $\begin{array}{l}0.290 * * \\
(0.050)\end{array}$ & $\begin{array}{l}0.226 * * \\
(0.067)\end{array}$ & $\begin{array}{l}0.356^{* *} \\
(0.057)\end{array}$ & $\begin{array}{l}0.292^{* *} \\
(0.078)\end{array}$ & $\begin{array}{l}0.323^{* *} \\
(0.056)\end{array}$ & $\begin{array}{l}0.265^{* *} \\
(0.080)\end{array}$ \\
\hline 62 & $\begin{array}{l}0.232 * * \\
(0.064)\end{array}$ & $\begin{array}{l}0.041 \\
(0.067)\end{array}$ & $\begin{array}{l}0.282^{* *} \\
(0.075)\end{array}$ & $\begin{array}{l}0.126 \\
(0.091)\end{array}$ & $\begin{array}{l}0.236 * * \\
(0.070)\end{array}$ & $\begin{array}{l}0.158 * \\
(0.093)\end{array}$ \\
\hline 63 and older & $\begin{array}{l}0.287 * * \\
(0.078)\end{array}$ & $\begin{array}{l}0.105 \\
(0.078)\end{array}$ & $\begin{array}{l}0.396 * * \\
(0.082)\end{array}$ & $\begin{array}{l}0.149 * \\
(0.087)\end{array}$ & $\begin{array}{l}0.365 * * \\
(0.085)\end{array}$ & $\begin{array}{l}0.202^{* *} \\
(0.095)\end{array}$ \\
\hline $\mathbf{N}$ & 3258 & 1508 & 2651 & 1184 & 3232 & 1320 \\
\hline Mean of dependent variable & 0.202 & 0.174 & 0.219 & 0.188 & 0.166 & 0.151 \\
\hline Chi-squared (25) & 296.161 & 94.446 & 245.224 & 98.915 & 280.813 & 98.966 \\
\hline Pseudo R-squared & 0.101 & 0.067 & 0.105 & 0.090 & 0.112 & 0.088 \\
\hline
\end{tabular}

Source: Authors' estimates from 1992-2008 waves of the Health and Retirement Study (HRS).

Note: The table reports marginal effects estimated from discrete-time hazard models, in which the dependent variable equaled one if the respondent stopped working, retired, or both stopped working and retired by the next wave (zero otherwise). Standard errors are shown in parentheses. The sample was restricted to noninstitutionalized men age 55 to 59 in 1992 and age 55 to 59 in 2002 who were working at baseline. They were observed for up to six years until they retired or dropped out of the sample.

$* 0.05<p<0.1$

** $p<0.05$ 
Table 5. Estimated Marginal Effects on the Likelihood of Retirement for Women in the 1933-37 and 1943-47 Birth Cohorts, Under Alternative Retirement Definitions

\begin{tabular}{|c|c|c|c|c|c|c|}
\hline & \multicolumn{2}{|c|}{ Stop Work } & \multicolumn{2}{|c|}{$\begin{array}{c}\text { Describe Oneself as } \\
\text { Retired }\end{array}$} & \multicolumn{2}{|c|}{$\begin{array}{c}\text { Stop Work and } \\
\text { Retired } \\
\end{array}$} \\
\hline & $\begin{array}{l}\text { 1933-37 } \\
\text { (Silent G.) } \\
\end{array}$ & $\begin{array}{l}\text { 1943-47 } \\
\text { (Boomers) } \\
\end{array}$ & $\begin{array}{l}\text { 1933-37 } \\
\text { (Silent G.) } \\
\end{array}$ & $\begin{array}{l}\text { 1943-47 } \\
\text { (Boomers) } \\
\end{array}$ & $\begin{array}{l}\text { 1933-37 } \\
\text { (Silent G.) }\end{array}$ & $\begin{array}{l}\text { 1943-47 } \\
\text { (Boomers) }\end{array}$ \\
\hline \multicolumn{7}{|l|}{ Education } \\
\hline Did not complete high school & $\begin{array}{l}-0.013 \\
(0.022)\end{array}$ & $\begin{array}{l}0.051 \\
(0.039)\end{array}$ & $\begin{array}{l}-0.035^{*} \\
(0.020)\end{array}$ & $\begin{array}{l}0.028 \\
(0.034)\end{array}$ & $\begin{array}{l}-0.024 \\
(0.017)\end{array}$ & $\begin{array}{l}0.023 \\
(0.030)\end{array}$ \\
\hline [Reference: High school graduate] & - & - & - & - & - & - \\
\hline Some college, fewer than 4 years & $\begin{array}{l}-0.007 \\
(0.022)\end{array}$ & $\begin{array}{l}-0.005 \\
(0.024)\end{array}$ & $\begin{array}{l}-0.012 \\
(0.021)\end{array}$ & $\begin{array}{l}0.002 \\
(0.023)\end{array}$ & $\begin{array}{l}-0.008 \\
(0.018)\end{array}$ & $\begin{array}{l}0.005 \\
(0.020)\end{array}$ \\
\hline Bachelor's degree or more & $\begin{array}{l}0.010 \\
(0.025)\end{array}$ & $\begin{array}{l}0.001 \\
(0.026)\end{array}$ & $\begin{array}{l}0.023 \\
(0.025)\end{array}$ & $\begin{array}{l}-0.007 \\
(0.025)\end{array}$ & $\begin{array}{l}0.023 \\
(0.022)\end{array}$ & $\begin{array}{l}-0.012 \\
(0.022)\end{array}$ \\
\hline \multicolumn{7}{|l|}{ Race } \\
\hline African American & $\begin{array}{l}0.004 \\
(0.023)\end{array}$ & $\begin{array}{l}0.068 * * \\
(0.034)\end{array}$ & $\begin{array}{l}-0.003 \\
(0.021)\end{array}$ & $\begin{array}{l}0.063^{*} \\
(0.034)\end{array}$ & $\begin{array}{l}-0.011 \\
(0.018)\end{array}$ & $\begin{array}{l}0.049 * \\
(0.029)\end{array}$ \\
\hline Hispanic & $\begin{array}{l}-0.024 \\
(0.033)\end{array}$ & $\begin{array}{l}0.116 * * \\
(0.046)\end{array}$ & $\begin{array}{l}-0.048 \\
(0.029)\end{array}$ & $\begin{array}{l}0.096 * * \\
(0.041)\end{array}$ & $\begin{array}{l}-0.052 * * \\
(0.023)\end{array}$ & $\begin{array}{l}0.087 * * \\
(0.038)\end{array}$ \\
\hline Other & $\begin{array}{l}-0.061 \\
(0.055)\end{array}$ & $\begin{array}{l}0.085 \\
(0.077)\end{array}$ & $\begin{array}{l}-0.042 \\
(0.053)\end{array}$ & $\begin{array}{l}-0.015 \\
(0.064)\end{array}$ & $\begin{array}{l}-0.058 \\
(0.041)\end{array}$ & $\begin{array}{l}-0.033 \\
(0.049)\end{array}$ \\
\hline [Reference: Non-Hispanic white] & - & - & - & - & - & - \\
\hline Married & $\begin{array}{l}0.056 * * \\
(0.018)\end{array}$ & $\begin{array}{l}0.036 * \\
(0.021)\end{array}$ & $\begin{array}{l}0.052 * * \\
(0.017)\end{array}$ & $\begin{array}{l}0.020 \\
(0.020)\end{array}$ & $\begin{array}{l}0.044^{* *} \\
(0.015)\end{array}$ & $\begin{array}{l}0.019 \\
(0.017)\end{array}$ \\
\hline Health-related work limitation & $\begin{array}{l}0.083 * * \\
(0.032)\end{array}$ & $\begin{array}{l}0.182 * * \\
(0.040)\end{array}$ & $\begin{array}{l}0.111^{* *} \\
(0.030)\end{array}$ & $\begin{array}{l}0.164 * * \\
(0.038)\end{array}$ & $\begin{array}{l}0.059 * * \\
(0.025)\end{array}$ & $\begin{array}{l}0.145^{* *} \\
(0.034)\end{array}$ \\
\hline Fair or poor health & $\begin{array}{l}0.104^{* *} \\
(0.029)\end{array}$ & $\begin{array}{l}0.052 * \\
(0.028)\end{array}$ & $\begin{array}{l}0.103 * * \\
(0.028)\end{array}$ & $\begin{array}{l}0.044 \\
(0.028)\end{array}$ & $\begin{array}{l}0.084^{* *} \\
(0.025)\end{array}$ & $\begin{array}{l}0.021 \\
(0.024)\end{array}$ \\
\hline Retiree health insurance offered & $\begin{array}{l}0.045^{* *} \\
(0.019)\end{array}$ & $\begin{array}{l}0.031 \\
(0.022)\end{array}$ & $\begin{array}{l}0.029 \\
(0.018)\end{array}$ & $\begin{array}{l}0.047 * * \\
(0.022)\end{array}$ & $\begin{array}{l}0.026 * \\
(0.015)\end{array}$ & $\begin{array}{l}0.040 * * \\
(0.019)\end{array}$ \\
\hline $\begin{array}{l}\text { Pension coverage } \\
\text { Defined benefit plan }\end{array}$ & $\begin{array}{l}-0.021 \\
(0.018)\end{array}$ & $\begin{array}{l}0.004 \\
(0.023)\end{array}$ & $\begin{array}{l}0.006 \\
(0.018)\end{array}$ & $\begin{array}{l}0.022 \\
(0.022)\end{array}$ & $\begin{array}{l}0.009 \\
(0.015)\end{array}$ & $\begin{array}{l}0.022 \\
(0.019)\end{array}$ \\
\hline Defined contribution plan only & $\begin{array}{l}-0.048 * * \\
(0.018)\end{array}$ & $\begin{array}{l}-0.077^{* *} \\
(0.020)\end{array}$ & $\begin{array}{l}-0.023 \\
(0.018)\end{array}$ & $\begin{array}{l}-0.065^{* *} \\
(0.019)\end{array}$ & $\begin{array}{l}-0.013 \\
(0.016)\end{array}$ & $\begin{array}{l}-0.055^{* *} \\
(0.017)\end{array}$ \\
\hline [Reference: None] & - & - & - & - & - & - \\
\hline $\begin{array}{l}\text { Log of previous wave's earnings } \\
(\$ 2008)\end{array}$ & $\begin{array}{l}-0.009 * * \\
(0.003)\end{array}$ & $\begin{array}{l}-0.002 \\
(0.003)\end{array}$ & $\begin{array}{l}-0.009 * * \\
(0.003)\end{array}$ & $\begin{array}{l}-0.002 \\
(0.003)\end{array}$ & $\begin{array}{l}-0.004 \\
(0.002)\end{array}$ & $\begin{array}{l}-0.000 \\
(0.002)\end{array}$ \\
\hline $\begin{array}{l}\text { Log of previous wave's household } \\
\text { wealth (excluding housing) (\$2008) }\end{array}$ & $\begin{array}{l}0.012 * * \\
(0.005)\end{array}$ & $\begin{array}{l}0.000 \\
(0.006)\end{array}$ & $\begin{array}{l}0.016 * * \\
(0.005)\end{array}$ & $\begin{array}{l}0.013 * * \\
(0.006)\end{array}$ & $\begin{array}{l}0.012 * * \\
(0.004)\end{array}$ & $\begin{array}{l}0.013 * * \\
(0.005)\end{array}$ \\
\hline
\end{tabular}

(continued) 
Table 5. (continued)

\begin{tabular}{|c|c|c|c|c|c|c|}
\hline & \multicolumn{2}{|c|}{ Stop Work } & \multicolumn{2}{|c|}{$\begin{array}{c}\text { Describe Oneself as } \\
\text { Retired } \\
\end{array}$} & \multicolumn{2}{|c|}{$\begin{array}{l}\text { Stop Work and } \\
\text { Retired }\end{array}$} \\
\hline & $\begin{array}{l}\text { 1933-37 } \\
\text { (Silent G.) }\end{array}$ & $\begin{array}{l}1943-47 \\
\text { (Boomers) }\end{array}$ & $\begin{array}{l}1933-37 \\
\text { (Silent G.) }\end{array}$ & $\begin{array}{l}1943-47 \\
\text { (Boomers) }\end{array}$ & $\begin{array}{l}1933-37 \\
\text { (Silent G.) }\end{array}$ & $\begin{array}{l}1943-47 \\
\text { (Boomers) }\end{array}$ \\
\hline $\begin{array}{l}\text { Zero or negative household wealth } \\
\text { (excluding housing) in previous year }\end{array}$ & $\begin{array}{l}0.153^{* *} \\
(0.077)\end{array}$ & $\begin{array}{l}-0.046 \\
(0.060)\end{array}$ & $\begin{array}{l}0.174^{* *} \\
(0.080)\end{array}$ & $\begin{array}{l}0.087 \\
(0.091)\end{array}$ & $\begin{array}{l}0.132 * \\
(0.069)\end{array}$ & $\begin{array}{l}0.111 \\
(0.091)\end{array}$ \\
\hline \multicolumn{7}{|l|}{ Age } \\
\hline [Reference: 55] & - & - & - & - & - & - \\
\hline 56 & $\begin{array}{l}0.020 \\
(0.046)\end{array}$ & $\begin{array}{l}-0.004 \\
(0.048)\end{array}$ & $\begin{array}{l}0.070 \\
(0.055)\end{array}$ & $\begin{array}{l}0.085 \\
(0.069)\end{array}$ & $\begin{array}{l}0.068 \\
(0.052)\end{array}$ & $\begin{array}{l}0.060 \\
(0.063)\end{array}$ \\
\hline 57 & $\begin{array}{l}0.098^{* *} \\
(0.045)\end{array}$ & $\begin{array}{l}-0.006 \\
(0.040)\end{array}$ & $\begin{array}{l}0.099 * * \\
(0.050)\end{array}$ & $\begin{array}{l}0.088 \\
(0.055)\end{array}$ & $\begin{array}{l}0.119 * * \\
(0.051)\end{array}$ & $\begin{array}{l}0.093^{*} \\
(0.054)\end{array}$ \\
\hline 58 & $\begin{array}{l}0.140^{* *} \\
(0.046)\end{array}$ & $\begin{array}{l}0.106^{* *} \\
(0.048)\end{array}$ & $\begin{array}{l}0.190^{* *} \\
(0.054)\end{array}$ & $\begin{array}{l}0.183^{* *} \\
(0.065)\end{array}$ & $\begin{array}{l}0.200 * * \\
(0.055)\end{array}$ & $\begin{array}{l}0.179 * * \\
(0.063)\end{array}$ \\
\hline 59 & $\begin{array}{l}0.153^{* *} \\
(0.044)\end{array}$ & $\begin{array}{l}0.100^{* *} \\
(0.043)\end{array}$ & $\begin{array}{l}0.195^{* *} \\
(0.051)\end{array}$ & $\begin{array}{l}0.153^{* *} \\
(0.056)\end{array}$ & $\begin{array}{l}0.188^{* *} \\
(0.051)\end{array}$ & $\begin{array}{l}0.140 * * \\
(0.054)\end{array}$ \\
\hline 60 & $\begin{array}{l}0.312^{* *} \\
(0.052)\end{array}$ & $\begin{array}{l}0.113^{* *} \\
(0.053)\end{array}$ & $\begin{array}{l}0.361^{* *} \\
(0.060)\end{array}$ & $\begin{array}{l}0.255^{* *} \\
(0.072)\end{array}$ & $\begin{array}{l}0.366 * * \\
(0.062)\end{array}$ & $\begin{array}{l}0.217^{* *} \\
(0.069)\end{array}$ \\
\hline 61 & $\begin{array}{l}0.408^{* *} \\
(0.052)\end{array}$ & $\begin{array}{l}0.201^{* *} \\
(0.057)\end{array}$ & $\begin{array}{l}0.498^{* *} \\
(0.055)\end{array}$ & $\begin{array}{l}0.338^{* *} \\
(0.073)\end{array}$ & $\begin{array}{l}0.473 * * \\
(0.060)\end{array}$ & $\begin{array}{l}0.301^{* *} \\
(0.072)\end{array}$ \\
\hline 62 & $\begin{array}{l}0.365^{* *} \\
(0.068)\end{array}$ & $\begin{array}{l}0.163^{* *} \\
(0.073)\end{array}$ & $\begin{array}{l}0.404 * * \\
(0.075)\end{array}$ & $\begin{array}{l}0.315^{* *} \\
(0.088)\end{array}$ & $\begin{array}{l}0.421^{* *} \\
(0.077)\end{array}$ & $\begin{array}{l}0.322 * * \\
(0.087)\end{array}$ \\
\hline 63 and older & $\begin{array}{l}0.466 * * \\
(0.069)\end{array}$ & $\begin{array}{l}0.255^{* *} \\
(0.081)\end{array}$ & $\begin{array}{l}0.543 * * \\
(0.067)\end{array}$ & $\begin{array}{l}0.388^{* *} \\
(0.091)\end{array}$ & $\begin{array}{l}0.577 * * \\
(0.066)\end{array}$ & $\begin{array}{l}0.413^{* *} \\
(0.089)\end{array}$ \\
\hline $\mathbf{N}$ & 2826 & 1893 & 2696 & 1815 & 3070 & 2008 \\
\hline Mean of dependent variable & 0.241 & 0.213 & 0.218 & 0.188 & 0.187 & 0.167 \\
\hline Chi-squared (25) & 231.006 & 125.172 & 282.090 & 125.567 & 278.289 & 124.950 \\
\hline Pseudo R-squared & 0.076 & 0.064 & 0.103 & 0.079 & 0.096 & 0.075 \\
\hline
\end{tabular}

Source: Authors' estimates from 1992-2008 waves of the Health and Retirement Study (HRS).

Note: The table reports marginal effects estimated from discrete-time hazard models, in which the dependent variable equaled one if the respondent stopped working, retired, or both stopped working and retired by the next wave (zero otherwise). Standard errors are shown in parentheses. The sample was restricted to noninstitutionalized women age 55 to 59 in 1992 and age 55 to 59 in 2002 who were working at baseline. They were observed for up to six years, until they retired or dropped out of the sample.

* $0.05<p<0.1$

$* * p<0.05$ 
Table 6. Incidence of Work Transitions Between Ages 50 and 69 for Men and Women Not Retired at Age 49, by Sex and Birth Cohort (\%)

\begin{tabular}{|c|c|c|c|c|c|}
\hline \multirow[b]{2}{*}{ First Transition } & \multirow[b]{2}{*}{ Later Transitions } & \multicolumn{2}{|c|}{ Men } & \multicolumn{2}{|c|}{ Women } \\
\hline & & $\begin{array}{c}\text { 1913-17 } \\
\text { (G.I. Gen) }\end{array}$ & $\begin{array}{c}1933-37 \\
\text { (Silent Gen.) }\end{array}$ & $\begin{array}{c}\text { 1913-17 } \\
\text { (G.I. Gen) }\end{array}$ & $\begin{array}{c}1933-37 \\
\text { (Silent Gen.) }\end{array}$ \\
\hline None (never retir & & 5.8 & 5.7 & 2.1 & $6.8 * \star \star$ \\
\hline \multirow[t]{5}{*}{ Partially Retire } & None (remain partially retired) & 7.7 & $12.1 * \star \star$ & 2.9 & $6.7 * \star \star$ \\
\hline & $\begin{array}{l}\text { Move from partial to full } \\
\text { retirement and never return to } \\
\text { work }\end{array}$ & 9.7 & 11.6 & 7.3 & $10.5^{\star *}$ \\
\hline & Unretire at some point & 14.7 & 18.1 * & 14.3 & $21.5^{\star \star \star}$ \\
\hline & Other & 0.7 & $3.7^{\star \star \star \star ~}$ & 0.8 & $2.6^{\star \star \star}$ \\
\hline & Total & 32.8 & $45.4^{\star * \star}$ & 25.3 & $41.3 * \star \star$ \\
\hline \multirow[t]{4}{*}{ Fully Retire } & None (remain fully retired) & 51.1 & 34.3 *** & 60.1 & $37.4 * \star \star$ \\
\hline & Unretire at some point & 4.9 & $7.5 * *$ & 7.8 & 7.7 \\
\hline & Other & 5.4 & 7.0 & 4.6 & 6.8 * \\
\hline & Total & 61.3 & 48.9 *** & 72.6 & $51.9^{* \star *}$ \\
\hline \multicolumn{2}{|c|}{ Number of observations } & 679 & 1,039 & 427 & 844 \\
\hline
\end{tabular}

Source: Authors' calculations from the SIPP, matched to administrative earnings records.

Note: The sample was restricted to adults who were working full-time (or nearly full-time) at age 49 . Workers were classified as having retired when they experienced a significant drop in their earnings (partially retired) or first received zero earnings in a calendar year (fully retired). Asterisks indicate that the value differed significantly from the value for the 1913-17 cohort $\left(* .05<\mathrm{p}<.10 ;{ }^{* *} .01<\mathrm{p}<.05 ;{ }^{* * *} \mathrm{p}<.01\right)$. 
Table 7. Incidence of Work Transitions Between Ages 50 and 69 for Men Not Retired at Age 49, by Education and Birth Cohort (\%)

\begin{tabular}{|c|c|c|c|c|c|c|c|}
\hline \multirow[b]{2}{*}{ First Transition } & \multirow[b]{2}{*}{ Later Transitions } & \multicolumn{2}{|c|}{$\begin{array}{c}\text { Not High School } \\
\text { Grad }\end{array}$} & \multicolumn{2}{|c|}{$\begin{array}{c}\text { High School } \\
\text { Grad }\end{array}$} & \multicolumn{2}{|c|}{$\begin{array}{c}\text { At Least Some } \\
\text { College }\end{array}$} \\
\hline & & $\begin{array}{c}1913-17 \\
\text { (G.I. Gen) } \\
\end{array}$ & $\begin{array}{c}\begin{array}{c}1933-37 \\
\text { (Silent G.) }\end{array} \\
\end{array}$ & $\begin{array}{c}1913-17 \\
\text { (G.I. Gen) } \\
\end{array}$ & $\begin{array}{c}\begin{array}{c}1933-37 \\
\text { (Silent G.) }\end{array} \\
\end{array}$ & $\begin{array}{r}1913-17 \\
\text { (G.I. Gen) } \\
\end{array}$ & $\begin{array}{c}\begin{array}{c}1933-37 \\
\text { (Silent G.) }\end{array} \\
\end{array}$ \\
\hline \multicolumn{2}{|l|}{ None (never retire) } & 3.6 & 2.7 & 5.6 & 2.9 & 9.1 & 8.2 \\
\hline \multirow[t]{5}{*}{ Partially Retire } & $\begin{array}{l}\text { None (remain partially } \\
\text { retired) }\end{array}$ & 6.6 & 5.1 & 6.7 & $16.2 * \star \star$ & 13.4 & 11.1 \\
\hline & $\begin{array}{l}\text { Move from partial to full } \\
\text { retirement and never } \\
\text { return to work }\end{array}$ & 10.6 & $19.0 * \star$ & 8.1 & 9.6 & 9.5 & 11.0 \\
\hline & Unretire at some point & 14.6 & 15.3 & 21.0 & 23.0 & 4.9 & $15.7^{\star * * *}$ \\
\hline & Other & 1.2 & 1.3 & 0.5 & 2.9 ** & 0.0 & $4.7^{\star \star \star \star}$ \\
\hline & Total & 33.1 & 40.7 & 36.3 & $51.7 * \star \star$ & 27.8 & $42.6 * \star *$ \\
\hline \multirow[t]{4}{*}{ Fully Retire } & $\begin{array}{l}\text { None (remain fully } \\
\text { retired) }\end{array}$ & 54.1 & 44.8 * & 50.9 & $34.0 * \star \star$ & 48.0 & 32.0 *** \\
\hline & Unretire at some point & 2.1 & 3.0 & 3.3 & 5.2 & 10.6 & 10.1 \\
\hline & Other & 7.1 & 8.8 & 3.9 & 6.1 & 4.4 & 7.1 \\
\hline & Total & 63.3 & 56.6 & 58.1 & $45.3 * \star \star$ & 63.1 & 49.2 *** \\
\hline \multicolumn{2}{|c|}{ Number of observations } & 307 & 152 & 208 & 338 & 136 & 536 \\
\hline
\end{tabular}

Source: Authors' calculations from the SIPP, matched to administrative earnings records.

Note: The sample was restricted to men who were working working full-time (or nearly full-time) at age 49 . Workers were classified as having retired when they experienced a significant drop in their earnings (partially retired) or first received zero earnings in a calendar year (fully retired). Asterisks indicate that the value differed significantly from the value for the 1913-17 cohort $(* .05<\mathrm{p}<.10 ; * * .01<\mathrm{p}<.05$; *** $\mathrm{p}<.01)$. 
Table 8. Incidence of Work Transitions Between Ages 50 and 69 for Women Not Retired at Age 49, by Education and Birth Cohort (\%)

\begin{tabular}{|c|c|c|c|c|c|c|c|}
\hline \multirow[b]{2}{*}{ First Transition } & \multirow[b]{2}{*}{ Later Transitions } & \multicolumn{2}{|c|}{$\begin{array}{c}\text { Not High School } \\
\text { Grad }\end{array}$} & \multicolumn{2}{|c|}{$\begin{array}{c}\text { High School } \\
\text { Grad }\end{array}$} & \multicolumn{2}{|c|}{$\begin{array}{l}\text { At Least Some } \\
\text { College }\end{array}$} \\
\hline & & $\begin{array}{l}\text { 1913-17 } \\
\text { (G.I. Gen' }\end{array}$ & $\begin{array}{c}1933-37 \\
\text { (Silent G.) } \\
\end{array}$ & $\begin{array}{c}1913-17 \\
\text { (G.I. Gen) } \\
\end{array}$ & $\begin{array}{c}\text { 1933-37 } \\
\text { (Silent G.) } \\
\end{array}$ & $\begin{array}{r}1913-17 \\
\text { (G.I. Gen) } \\
\end{array}$ & $\begin{array}{c}\text { 1933-37 } \\
\text { (Silent G.) } \\
\end{array}$ \\
\hline \multicolumn{2}{|c|}{ None (never retire) } & 4.7 & 3.8 & 0.0 & $2.9 * \star \star$ & 1.1 & $10.3 * \star \star$ \\
\hline \multirow[t]{5}{*}{ Partially Retire } & $\begin{array}{l}\text { None (remain partially } \\
\text { retired) }\end{array}$ & 0.0 & 2.6 * & 2.0 & $10.4 * \star \star$ & 6.9 & 4.6 \\
\hline & $\begin{array}{l}\text { Move from partial to full } \\
\text { retirement and never } \\
\text { return to work }\end{array}$ & 9.1 & 14.3 & 9.6 & 6.3 & 2.4 & 13.0 *** \\
\hline & Unretire at some point & 21.0 & 29.1 & 10.0 & $20.9 * \star *$ & 9.2 & $20.3 * \star *$ \\
\hline & Other & 0.0 & 0.0 & 0.0 & 5.4 & 2.9 & 1.1 \\
\hline & Total & 30.1 & $46.0 * \star \star$ & 21.7 & $43.0 * \star \star$ & 21.4 & 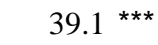 \\
\hline \multirow[t]{4}{*}{ Fully Retire } & $\begin{array}{l}\text { None (remain fully } \\
\text { retired) }\end{array}$ & 54.2 & 42.6 ** & 61.3 & $39.9 * \star \star$ & 67.5 & 34.4 *** \\
\hline & Unretire at some point & 6.9 & $1.4 * \star$ & 10.3 & 8.8 & 6.7 & 8.2 \\
\hline & Other & 4.1 & 6.3 & 6.7 & 5.4 & 3.2 & 8.0 ** \\
\hline & Total & 65.1 & 50.2 ** & 78.3 & $54.1 * \star \star$ & 77.5 & 50.6 *** \\
\hline \multicolumn{2}{|c|}{ Number of observations } & 164 & 125 & 139 & 296 & 103 & 418 \\
\hline
\end{tabular}

Source: Authors' calculations from the SIPP, matched to administrative earnings records.

Note: The sample was restricted to women who were working full time (or nearly full time) at age 49. Workers were classified as having retired when they experienced a significant drop in their earnings (partially retired) or first received zero earnings in a calendar year (fully retired). Asterisks indicate that the value differs significantly from the value for the 191317 cohort $(* .05<\mathrm{p}<.10 ; * * .01<\mathrm{p}<.05 ; * * * \mathrm{p}<.01)$. 


\section{RECENT WORKING PAPERS FROM THE CENTER FOR RETIREMENT RESEARCH AT BOSTON COLLEGE}

Spousal Health Shocks and the Timing of the Retirement Decision in the Face of ForwardLooking Financial Incentives

Courtney Harold Van Houtven and Norma B. Coe, June 2010

Incorporating Employee Heterogenity Into Default Rules for Retirement Plan Selection Gopi Shah Godi and Colleen Flaherty Manchester, May 2010

Accurately Measuring Health Over the Life Course

Fabian Lange and Doug McKee, May 2010

Getting to the Top of Mind: How Reminders Increase Saving Dean Karlan, Margaret McConnell, Sendhil Mullainathan, and Jonathan Zinman, April 2010

The Shrinking Tax Preference for Pension Savings: An Analysis of Income Tax Changes, 1985-2007

Gary Burtless and Eric Toder, March 2010

Social Security, Benefit Claiming and Labor Force Participation: A Quantitative General Equilibrium Approach

Selahattin Imrohoroğlu and Sagiri Kitao, March 2010

How Much Is Enough? The Distribution of Lifetime Health Care Costs

Anthony Webb and Natalia Zhivan, February 2010

Impact of Immigration on the Distribution of American Well-Being

Gary Burtless, December 2009

Actual and Anticipated Inheritance Receipts

Norma B. Coe and Anthony Webb, December 2009

Will Automatic Enrollment Reduce Employer Contributions to 401(k) Plans

Mauricio Soto and Barbara A. Butrica, December 2009

How Seniors Change Their Asset Holdings During Retirement

Karen Smith, Mauricio Soto, and Rudolph G. Penner, December 2009

All working papers are available on the Center for Retirement Research website (http://crr.bc.edu) and can be requested by e-mail (crr@bc.edu) or phone (617-552-1762). 